\title{
Treatment Alternatives for Non-Fuel-Bearing Hardware
}

W. A. Ross

L. L. Clark

K. H. Oma

January 1987

Prepared for the U.S. Department of Energy under Contract DE-AC06-76RLO 1830

Pacific Northwest Laboratory Operated for the U.S. Department of Energy by Battelle Memorial Institute 


\title{
DISCLAIMER
}

This report was prepared as an account of work sponsored by an agency of the United States Government. Neither the United States Government nor any agency thereof, nor Battelle Memorial Institute, nor any of their employees, makes any warranty, expressed or implied, or assumes any legal liability or responsibility for the accuracy, completeness, or usefulness of any information, apparatus, product, or process disclosed, or represents that its use would not infringe privately owned rights. Reference herein to any specific commercial product, process, or service by trade name, trademark, manufacturer, or otherwise, does not necessarily constitute or imply its endorsement, recommendation, or favoring by the United States Government of any agency thereof, or Battelle Memorial Institute. The views and opinions of authors expressed herein do not necessarly state.or reflect those of the United States Government or any agency thereof, or Battelle Memorial Institute.

\author{
PACIFIC NORTHWEST LABORATORY \\ operated by \\ BATTELLE \\ for the \\ UNITED STATES DEPARTMENT OF ENERGY \\ under Contract DE-ACO6-76RLO 1830
}

\begin{tabular}{|c|c|}
\hline \multicolumn{2}{|c|}{$\begin{array}{c}\text { Printed in the United States of America } \\
\text { Available from } \\
\text { National Technical Information Service } \\
\text { United States Department of Commerce } \\
5285 \text { Port Royal Road } \\
\text { Springfield, Virginia } 22161\end{array}$} \\
\hline \multicolumn{2}{|c|}{$\begin{array}{l}\text { NTIS Price Codes } \\
\text { Microfiche A01 }\end{array}$} \\
\hline \multicolumn{2}{|c|}{ Printed Copy } \\
\hline Pages & $\begin{array}{l}\text { Price } \\
\text { Codes }\end{array}$ \\
\hline $001-025$ & $\mathrm{~A} 02$ \\
\hline $026-050$ & A03 \\
\hline $051-075$ & $\mathrm{~A} 04$ \\
\hline $076-100$ & A05 \\
\hline $101-125$ & $\mathrm{~A} 06$ \\
\hline $126-150$ & $\mathrm{~A} 07$ \\
\hline $151-175$ & $A 08$ \\
\hline $176-200$ & $\mathrm{~A} 09$ \\
\hline $201-225$ & A010 \\
\hline $226-250$ & A011 \\
\hline $251-275$ & A012 \\
\hline $276-300$ & A013 \\
\hline
\end{tabular}


TREATMENT ALTERNATIVES FOR NON-FUEL-BEARING HARDWARE
W. A. Ross
L. L. Clark
K. H. Oma

January 1987

Prepared for the U.S. Department of Energy under Contract DE-AC06-76RLO 1830

Pacific Northwest Laboratory Richland, Washington 99352 

SUMMARY

This evaluation compares four alternatives for the treatment or processing of non-fuel bearing hardware (NFBH) to reduce its volume and prepare it for disposal. These treatment alternatives are:

- shredding

- shredding and low pressure compaction

- shredding and supercompaction

- melting.

These alternatives are compared on the basis of system costs, waste form characteristics, and process considerations, which include the characteristics noted below:

\begin{tabular}{lll} 
System Costs & $\begin{array}{c}\text { Waste Form } \\
\text { Characteristics }\end{array}$ & Process Consideration \\
\hline - treatment & - release rate & - operational safety \\
- transportation & - particulates & - process simplicity \\
- disposal & - pyrophorics & - status of technology \\
& - bulk density &
\end{tabular}

The study recommends that melting and supercompaction alternatives be further considered and that additional testing be conducted for these two alternatives.

This study was prepared for the U.S. Department of Energy (DOE) as part of the Nuclear Waste System Integration Program being conducted by the Pacific Northwest Laboratory (PNL). (a)

The NFBH in this evaluation is assumed to be from the consolidation of spent fuel rods at the Monitored Retrievable Storage (MRS) Facility. A total of 62,000 MTU of spent fuel is used for the economic analysis. A similar volume of NFBH would also be generated if fuel rod consolidation was performed at the repository. Processing of this amount of spent fuel is estimated to

(a) Operated by Battelle Memorial Institute for the Department of Energy under contract DE-ACO6-76RL0 1830. 
generate about 375 cubic meters of shredded hardware with a weight of 340,000 kilograms a year for 25 years. Other wastes from operation of the facility were not included in this study.

The four waste treatment alternatives provide a wide range of waste. volumes for the analysis and include the options most applicable to low-density metallic wastes. No alternatives that involve the separation of the NFBH into different waste streams for treatment and disposal are considered. The waste is assumed to be disposed of in a commercial repository with the spent fuel.

The economic analysis considers treatment, transportation, and disposal costs. The range of costs and potential savings for the four treatment alternatives are shown below in millions of dollars. A range of values is shown because of differences in the costs at three potential repositories.

\begin{tabular}{|c|c|c|c|c|c|}
\hline $\begin{array}{c}\text { Process } \\
\text { Alternative }\end{array}$ & $\begin{array}{c}\text { Treatment } \\
\text { Costs } \\
\end{array}$ & $\begin{array}{c}\text { Transportation } \\
\text { Costs } \\
\end{array}$ & $\begin{array}{l}\text { Minimum } \\
\text { Disposal } \\
\text { Costs }\end{array}$ & $\begin{array}{l}\text { Total } \\
\text { Costs } \\
\end{array}$ & $\begin{array}{c}\text { Potential } \\
\text { Savings }\end{array}$ \\
\hline Shredding & $60-65$ & $250-288$ & $310-476$ & $663-816$ & --- \\
\hline $\begin{array}{r}\text { Low-Pressure } \\
\text { Compaction }\end{array}$ & $44-46$ & $129-137$ & $155-298$ & $341-481$ & $>307$ \\
\hline Supercompaction & $61-64$ & $52-69$ & $86-215$ & $199-345$ & $>436$ \\
\hline Melting & $70-73$ & $42-64$ & $66-189$ & $182-309$ & $>478$ \\
\hline
\end{tabular}

The treatment costs include capital costs for facility and equipment an 1 operating costs, including the cost of canisters. A four-month interim storage area is included as part of the treatment facility and is a significant capial cost for the high-waste-volume alternatives. Decommissioning costs are also included but are not very large. The transportation costs are based on shipping the wastes 2000 miles by dedicated train. If rod consolidation occurs $z$ : the repository rather than at the MRS, the transportation costs would be the same for each alternative and would be part of the cost of shipping the spen: fuel assemblies.

Three disposal media (basalt, tuff, and salt) and two disposal options within each media are considered. The disposal costs are most significant fisr 
the high-volume alternatives, but they are comparable to the treatment and transportation costs for the low-volume alternatives. The results demonstrate the importance of volume reduction in waste treatment selection--at least for this type of waste. The overall potential cost savings of about $\$ 450 \mathrm{M}$ for the melting and supercompaction alternatives justifies the testing and development of the volume reduction technology for this application.

The characteristics of the waste forms and the processes used in these alternatives are compared using a qualitative method. Melted metal has the most desirable waste form characteristics, while the shredding alternative has the most desirable process characteristics.

A relative ranking of the treatment alternatives is summarized below with the better characteristics given a plus (+), intermediate characteristics a zero (0), and less desirable characteristics a minus (-).

\begin{tabular}{|c|c|c|c|}
\hline Alternative & $\begin{array}{c}\text { Cost } \\
\text { Ranking } \\
\end{array}$ & $\begin{array}{l}\text { Process } \\
\text { Ranking } \\
\end{array}$ & $\begin{array}{c}\text { Waste Form } \\
\text { Ranking }\end{array}$ \\
\hline Shredding & $(-)$ & $(+)$ & $(-)$ \\
\hline Low-Pressure Compaction & $(0)$ & $(0)$ & $(-)$ \\
\hline Supercompaction & $(+)$ & $(-)$ & $(0)$ \\
\hline Melting & $(+)$ & $(-)$ & $(+)$ \\
\hline
\end{tabular}

Based on the evaluation, both melting and supercompaction are recommended for further testing. After collection of detailed data from a testing program, the two aiternatives should again be compared and, if process concerns can be resolved, the better alternative selected for deployment in the MRS or at a repository (if the MRS is not implemented). 


\section{CONTENTS}

SUMMARY

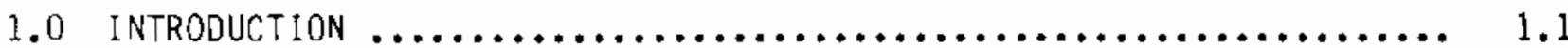

2.0 CONCLUSIONS AND RECOMMENDATIONS $\ldots \ldots \ldots \ldots \ldots \ldots \ldots \ldots \ldots \ldots \ldots \ldots \ldots$

2.1 GENERAL OBSERVATIONS AND CONCLUSIONS $\ldots \ldots \ldots \ldots \ldots \ldots \ldots \ldots \ldots . . \ldots$

2.2 RECOMMENDATIONS OF TREATMENT ALTERNATIVES FOR

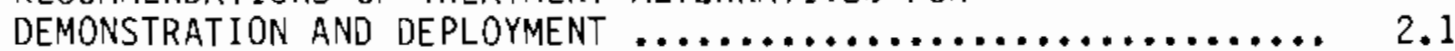

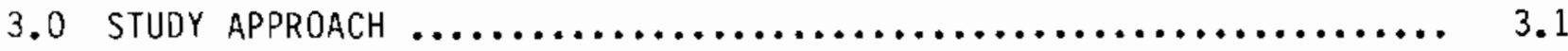

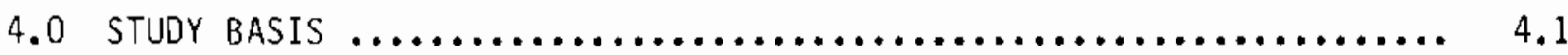

4.1 TECHNICAL BASES AND ASSUMPTIONS $\ldots \ldots \ldots \ldots \ldots \ldots \ldots \ldots \ldots \ldots \ldots \ldots . \ldots \ldots$

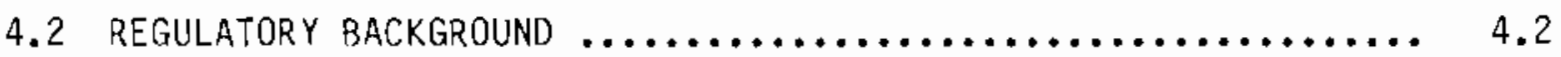

5.0 DEFINITION OF INITIAL WASTE STREAM $\ldots \ldots \ldots \ldots \ldots \ldots \ldots \ldots \ldots \ldots \ldots \ldots . \ldots \ldots$

6.0 WASTE TREATMENT PROCESSES AND THEIR RESULTING WASTE VOLUMES $\ldots \ldots \ldots, 6.1$

6.1 SHREdding ALtERnATIVE $\ldots \ldots \ldots \ldots \ldots \ldots \ldots \ldots \ldots \ldots \ldots \ldots \ldots \ldots \ldots \ldots$

6.2 SHREODING AND LOW-PRESSURE COMPACTION ALTERNATIVE $\ldots \ldots \ldots \ldots .6 .2$

6.3 SHREDDING AND SUPERCOMPACTION ALTERNATIVE $\ldots \ldots \ldots \ldots \ldots \ldots \ldots . . .6$

6.4 MELTING ALTERNATIVE $\ldots \ldots \ldots \ldots \ldots \ldots \ldots \ldots \ldots \ldots \ldots \ldots \ldots \ldots \ldots \ldots . \ldots \ldots$

7.0 COST CONSIDERATIONS $\ldots \ldots \ldots \ldots \ldots \ldots \ldots \ldots \ldots \ldots \ldots \ldots \ldots \ldots \ldots \ldots \ldots \ldots \ldots$

7.1 COST OF NFBH TREATMENT FACILITIES $\ldots \ldots \ldots \ldots \ldots \ldots \ldots \ldots \ldots \ldots \ldots . \ldots \ldots$

7.1.I Capital Costs for NFBH Treatment Facilities .......... 7.1

7.1.2 Operating Costs for NFBH Treatment Facilities ........ 7.2

7.1 .3 Summary of NFBH Facility Costs $\ldots \ldots \ldots \ldots \ldots \ldots \ldots \ldots . \ldots . \ldots . \ldots$

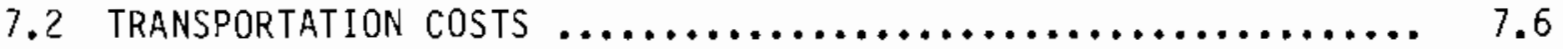

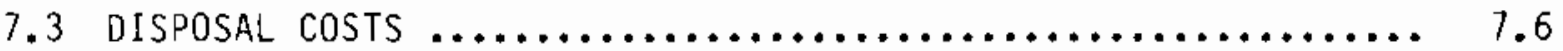

7.4 TOTAL LIFE $\rightarrow$ CYCLE COSTS $\ldots \ldots \ldots \ldots \ldots \ldots \ldots \ldots \ldots \ldots \ldots \ldots \ldots \ldots . . . . . . \ldots$ 
8.0 WASTE FORM AND PROCESS CONSIDERATIONS $\ldots \ldots \ldots \ldots \ldots \ldots \ldots \ldots \ldots \ldots . . .1$

8.1 WASTE FORM CONSIDERATIONS $\ldots \ldots \ldots \ldots \ldots \ldots \ldots \ldots \ldots \ldots \ldots \ldots . . .1$

8.2 PROCESS CONSIDERATIONS $\ldots \ldots \ldots \ldots \ldots \ldots \ldots \ldots \ldots \ldots \ldots \ldots \ldots \ldots \ldots, 8 \ldots \ldots \ldots$

8.2.1 Operational Safety $\ldots \ldots \ldots \ldots \ldots \ldots \ldots \ldots \ldots \ldots \ldots . . . \ldots .3$

8.2 .2 Process Simplicity $\ldots \ldots \ldots \ldots \ldots \ldots \ldots \ldots \ldots \ldots \ldots \ldots . . .6 .5$

8.2.3 Status of Technology $\ldots \ldots \ldots \ldots \ldots \ldots \ldots \ldots \ldots \ldots \ldots, 8.6$

8.2.4 Summary of Process Evaluation ................. 8.6

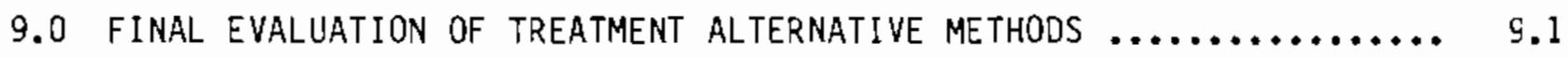

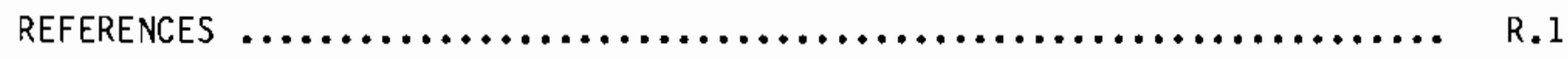

APPENDIX A - TREATMENT COSTS FOR NFBH TREATMENT ALTERNATIVES .......... A.I

APPENDIX B - TRANSPORTATION COSTS FOR NFBH TREATMENT ALTERNATIVES $\ldots . .$. B.I 


\section{FIGURES}

3.1 Technology Development and Application Process for NFBH Disposal

3.2 Flow Chart for TRUW Treatment Study $\ldots \ldots \ldots \ldots \ldots \ldots \ldots \ldots \ldots \ldots \ldots \ldots . \ldots \ldots$

6.1 Treatment of NFBH in the Disposal Process .................. 6.2

7.1 Lifetime Capital, Operating, and Decommissioning Costs of NFBH Treatment Atternatives ............................... 7.5

7.2 Lifetime Treatment, Transportation, and Disposal Costs for NFBH Treatment Alternatives .................................. 7.9 


\section{$\underline{\text { TABLES }}$}

5.1 Projected Annual Untreated Waste Volumes from Spent Fuel Rod

6.1 Annual Waste Volumes for Shredded NFBH

6.2 Annual Waste Volumes for Shredded and Low-Pressure Compacted NFBH

6.3 Annual Waste Volumes for Shredded and Supercompacted NFBH

6.4 Annual Waste Volumes for Melted NFBH

7.l Capital Costs for NFBH Treatment Alternatives

7.2 Annual Operating Costs for NFBH Treatment Alternatives with Basalt Canisters

7.3 Annual Operating Costs for NFBH Treatment Alternatives with Tuff Canisters

7.4 Annual Operating Costs for NFBH Treatment Alternatives with Salt Canisters

7.5 Lifetime Transportation Costs for NFBH Treatment Alternatives .....

7.6 Repository Disposal Costs for NFBH Treatment Alternatives $\ldots . . . . .7 \quad 7.3$

8.1 Evaluation of Waste Form Characteristics for Process Alternatives

8.2 Evaluation of Process Characteristics for Treatment Alternatives

9.1 Comparison of Strengths and Weaknesses of Treatment Alternatives

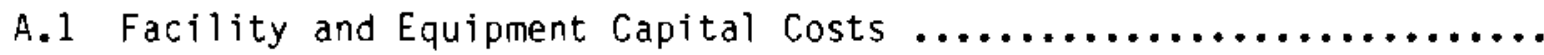

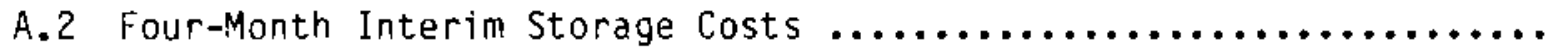

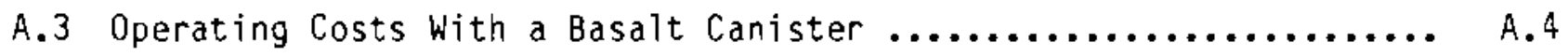

A.4 Operating Costs With a Tuff Canister $\ldots \ldots \ldots \ldots \ldots \ldots \ldots \ldots \ldots \ldots \ldots \ldots \ldots$ A.5

A.5 Operating Costs With a Salt Canister $\ldots \ldots \ldots \ldots \ldots \ldots \ldots \ldots \ldots \ldots \ldots$ A.6

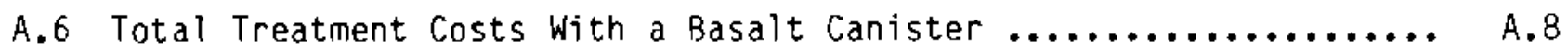


A.7 Total Treatment Costs with a Tuff Canister .................. A.9

A.8 Total Treatment Costs With a Salt Canister ......................... A0

B.1 Transportation Costs for NFBH Treatment Alternatives with

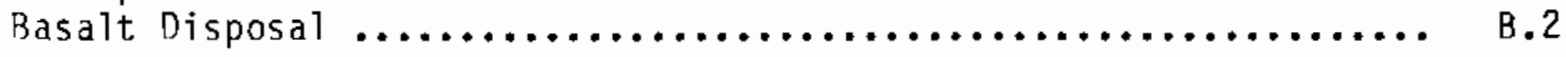

B.2 Transportation Costs for NFBH Treatment Alternatives with

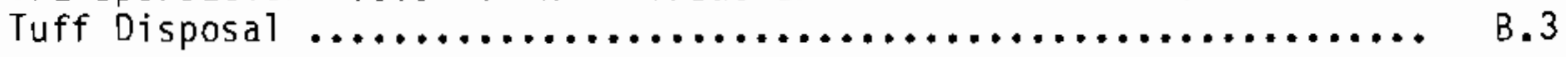

B.3 Transportation Costs for NFBH Treatment Alternatives with

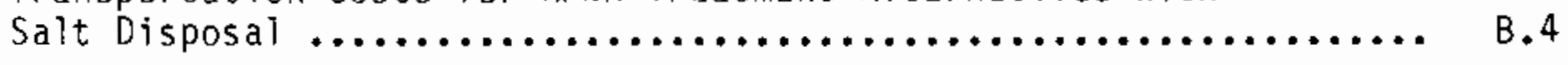




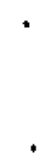




\subsection{INTRODUCTION}

The study documented in this report was performed for the Department of Energy (DOE) as part of the Nuclear Waste Systems Integration Program (NWSI) being conducted by Pacific Northwest Laboratory (PNL). The objective of this study is to provide an analysis of treatment alternatives for non-fuel-bearing hardware (NFBH). No other waste types are considered. The current study is a follow-up to a study of treatment alternatives for all types of potential commercial transuranic waste (TRUW) and high-activity waste (HAW) that may exist in the U.S. (Ross et al. 1986). This NFBH study uses a similar general approach and the same basic data as the more comprehensive study.

The NFBH will be generated during the commercial spent fuel handling and consolidation operations at either a Monitored Retrievable Storage (MRS) facility (U.S. DOE 1986), if approved by Congress, or at a receiving and handling facility at a deep geologic repository. Proposed at-reactor fuel rod consolidation will also generate a form of consolidated hardware that may be received by either the MRS or the repository.

The MRS facility is proposed to be a central facility for consolidation and interim storage of commercial spent fuel assemblies. If the MRS facility is not built, the geologic repository will have equivalent facilities for consolidating and packaging the incoming spent fuel and HLW. The repository facilities will generate amounts of TRUW and HAW similar to those expected to be generated by the MRS facility.

The NFBH may be either TRUW or HAW. Transuranic waste is defined as material contaminated with TRU radionuclides in concentrations greater than $100 \mathrm{nCi} / \mathrm{g}$. Only the NFBH contaminated with spent fuel materials from rod failures during the consolidation process is considered a TRUW. High-activity waste is defined for this report as waste that exceeds the Class C low-levelwaste (LLW) limits specified in 10 CFR 61 but is not TRUW. The NFBH has been subjected to high neutron fluxes, and activation products have been created as a result. Cobalt-60, niobium-94, and nicke1-59 are the radioactive isotopes most commonly formed in sufficient concentrations to be of concern. Concentrations of these three isotopes in NFBH are not well characterized and will 
likely exceed the limits for Class C LLW as defined in 10 CFR 61 (Luksic, et a1. 1986). Such NFBH is not normally acceptable for LLW disposal. The current system requirements indicate that the NFBH will be disposed of in a commercial repository (DOE 1986a). In this case the NFBH, in combination with engineered barriers in the repository, may be required to meet the U.S. Nuclear Regulatory Commission's (NRC's) requirements in 10 CFR 60. However, acceptarce requirements for disposal of the NFBH have not yet been established.

Four alternatives for the treatment of the NFBH were evaluated in this study and are described in this report. The results of the study provide the DOE with a basis for making preliminary decisions about the development and testing of treatment technology for the NFBH. 


\subsection{CONCLUSIONS AND RECOMMENDATIONS}

Four alternatives for the treatment of non-fuel-bearing hardware have been evaluated. This evaluation has considered waste form characteristics, processing characteristics, and economics. Two types of conclusions and recommendations can be made as a result of this evaluation: first, general observations from preparing the study; second, recommendations on the preferred alternatives and further work.

\subsection{GENERAL OBSERVATIONS AND CONCLUSIONS}

- The waste form acceptance requirements for disposal of NFBH have not yet been defined. The lack of definitive requirements for the waste forms makes the acceptability of a waste form uncertain and therefore leaves in question some conclusions of this and related studies.

- Large uncertainties exist on the radiation dose and heat generation rate of $\mathrm{NFBH}$.

- There are significant opportunities to reduce the volume of the NFBH by treatment. Volume reduction by a factor of up to 10 is possible.

- Volume reduction generally increases the quality of the waste forms.

- Volume reduction can reduce total system costs. Transportation and disposal costs are very sensitive to total volume.

- Total system savings of $\$ 400$ to $\$ 500$ million are possible with the melting and supercompaction alternatives compared to the reference shredding a Tternative.

2.2 RECOMMENDATIONS OF TREATMENT ALTERNATIVES FOR DEMONSTRATION AND DEPLOYMENT

- The melting alternative is favored from the standpoint of system economics and waste form quality.

- The supercompaction alternative will also provide major savings in system costs. The waste form quality from this alternative is poorer 
than that from melting, but it should be adequate since the NFBH would be acceptable for disposal without any treatment if it were part of a spent fuel assembly.

- Further testing and evaluation of both the meiting and the supercompaction alternatives should be conducted to provide more reliable data upon which to make final recommendations for use in the MRS. Testing of the processes with simulated wastes should be conducted, and the design and process requirements should be carefully evaluated.

- Characterization of NFBH should be conducted to reduce concerns about shielding requirements and thermal power. 


\subsection{STUDY APPROACH}

This study builds upon a more comprehensive study that considered all of the existing comrnercial TRUW and HAW (Ross et al. 1986). The purpose of this study is to compare the alternative technologies for treatment of NFBH at the MRS or repository facilities without considering other waste streams. The various steps suggested for the development and application of treatment technology are illustrated in Figure 3.1. Following this analysis, development and demonstration activities are identified for the key elements of the preferred alternatives. These activities include early development of selected treatment

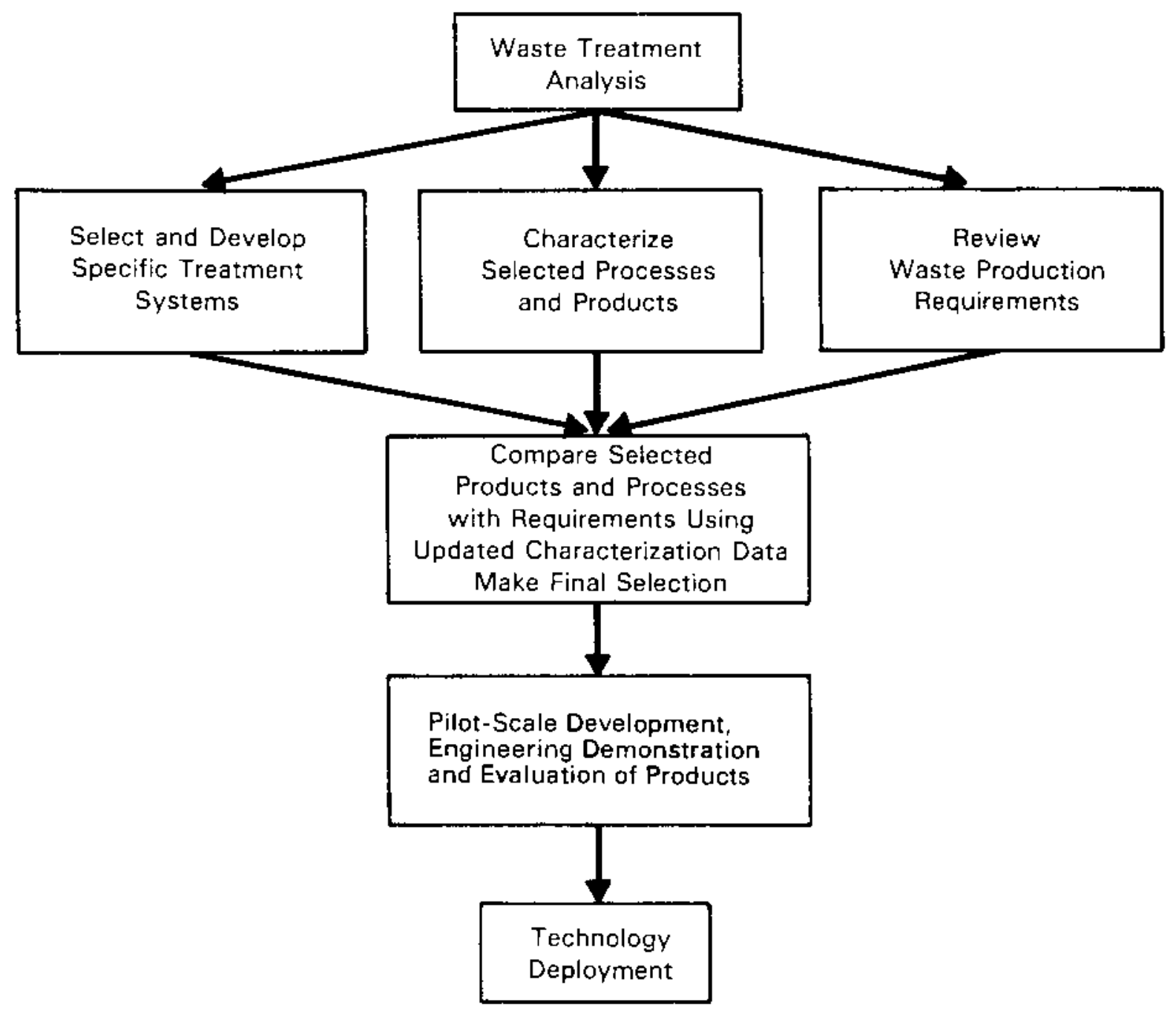

FIGURE 3.1. Technology Development and Application Process for NFBH Disposal 
alternatives and more detailed evaluation of specific components and configurations within the treatment system. For example, the location of the process units within the MRS must be identified, and the construction materials and operation methods must be evaluated further. Concurrent with equipment and process development, waste forms would be characterized and evaluated durinc the early process development period to meet production needs and waste acceftance criteria (WAC). Following these activities, specific technologies would be selected, and pilot-scale processes would be demonstrated using nonradioactive and possibly radioactive materials. The full-scale demonstrations should also be conducted in conjunction with the cold checkout of the handling facilities. The time allowed for these activities is short, with current (tut potentially delayed) MRS milestones for the selection of the treatment alternative in March 1987, for submittal of a license application in January 1989, and for equipment to be designed and installed for the prototype tests of the consolidation equipment in March 1990 (U.S. DOE 1985).

This study followed the steps identified in Figure 3.2. The first step was to identify the study bases, described in Section 4.0. Information from the most current plans for the MRS facility design was obtained and integrated into the waste-generation data provided in Section 5.0. Four possible treatment alternatives were examined (see Section 6.0). Available information was then used to calculate the volumes of treated waste and to define the waste forms that would be generated by the treatment alternative processes (see Section 6.0). The treated waste volumes are the key factors in determining transportation and disposal costs, and also impact the process equipment requirements and processing costs given in Section 7.0 . The waste forms postulated to be generated from all of the treatment alternatives and the processes to be used in the alternatives were identified, rated, and ranked (see Sections 8.1 and 8.2). A summary of the consideration and tradeoffs (Section 9.0) and conclusions and recommendations (Section 2.0) were finally prepared. 


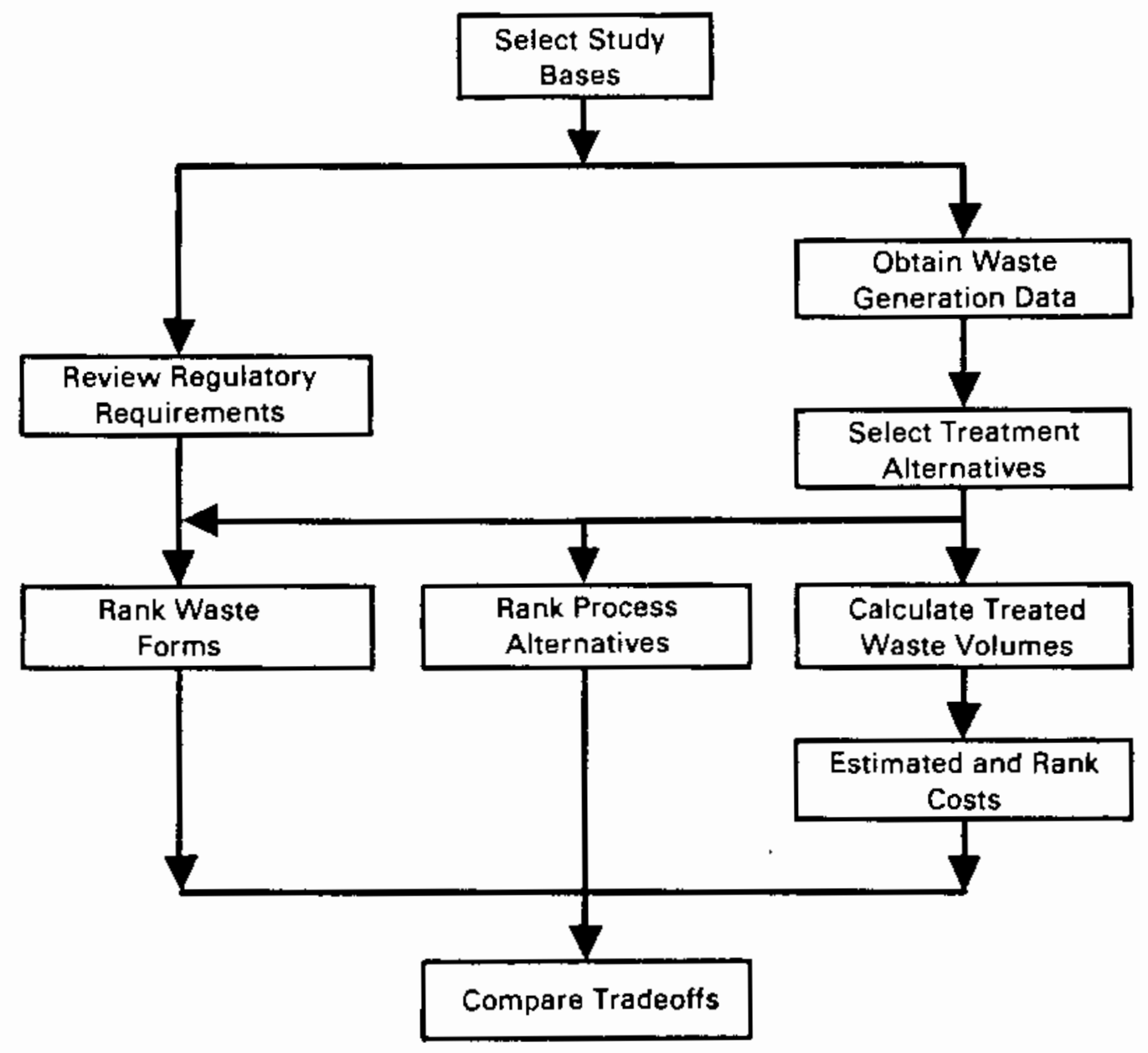

FIGURE 3.2. Flow Chart for TRUW Treatment Study 


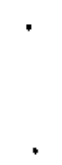




\subsection{STUDY BASIS}

This section identifies the major technical bases and assumptions and the regulatory background for this study. The bases were applied to the overall study approach described in Section 3.0 and were used to develop the detailed data and analysis presented in the subsequent sections.

\subsection{TECHNICAL BASES AND ASSUMPTIONS}

The major technical bases and assumptions used in the study are given below:

- The report considers the reference system to be consolidation of the spent fuel at the MRS, rail shipment of the MFBH to the repository, and the emplacement of the NFBH into a geologic repository. The NFBH will not be separated into any substreams for special treatment.

- The NFBH is the only waste stream of concern. The impacts and interactions with other streams are not considered. The NFBH will be remote-handled because of the neutron activation of the materials in the NFBH.

- The NFBH may or may not be TRUW, but the distinction is not considered important since the wastes are considered to be going to the geologic repository (U.S. DOE 1986a) and will be required to meet the NRC's 10 CFR 60 requirements for wastes in the repository (NRC 1983).

- Transuranic waste and HAW considered here are assumed to be disposed of in the same commercial repository with spent fuel and HLW. For economic comparison, both placement in heavy overpacks between the spent fuel packages and placement in a separate part of the repository without heavy overpacks have been considered.

- The Conceptual Design of the MRS (Ralph M. Parsons Co., Westinghouse Electric Corp. and Golder Associates 1985) is used as the bases for process layouts and interactions with other parts of the waste management system. 
- The processing rate for spent fuel is $2500 \mathrm{MTU} / \mathrm{yr}$ with a total throughput of 62,000 MTU. This rate implies a facility life of 25 years.

- Waste volumes are those estimated by Luksic et al. (1986) with adjustments to the current processing rate $(2500 \mathrm{MTU} / \mathrm{yr})$.

- Repository costs are determined by estimating the repository waste handling building, transport, and emplacement costs underground and the cost of additional repository borehole, room, ventilation, and excavation requirements.

\subsection{REGULATORY BACKGROUND}

It is planned that the NFBH will be sent to the repository for disposal (DOE 1986). This means that the NFBH must comply with federal regulations for interim storage, transportation, and disposal. Potential requirements were discussed previously (Ross et a1. 1986 and Luksic et al. 1986) and are not repeated here. The potential requirements of concern for the NFBH are similar to the other repository wastes and may include:

- Low release rate

- Immobilized particulates

- No pyrophoric potential

- Structural stability.

The low release rate requirement results from 10 CFR 60 (NRC 1983), which states in the foreword to the actual regulation, "The release requirements in 60.113 apply to all radionuclides that... may be disposed of at a geological repository." Section 60.113 states the requirement that the fractional release rate from the engineered barrier must be less than one part in $10^{5}$ per year.

The particulates requirement is also part of 10 CFR 60 , which states "Particulate waste forms shall be consolidated." In the Waste Isolation Pilot Plant Waste Acceptance Requirements, wastes containing greater than 1\% particles of a size less than 10 microns are required to be solidified (TWSO 1982). 
Pyrophorics are also prohibited by 10 CFR 60. It is recognized that zirconium metal of a fine particle size can be pyrophoric. It is not known what particle size distribution is needed for the material to be pyrophoric.

The Draft Waste Acceptance Requirements for acceptance of the vitrified HLW at the repositories limits the free volume in the waste container (U.S. DOE 1986c). This limit is based on the concern that failure of the canister could result in the backfill materials flowing into the canister and tbereby reducing its effectiveness around the canister.

These potential requirements are used in Section 8.0 to compare the relative attractiveness of the waste forms resulting from the selected processes. It is recognized that some of the potential requirements may in fact not become actual requirements or may be modified during the development of the waste acceptance requirements for NFBH waste. It is also possible that additional requirements may be identified. 


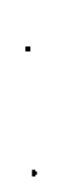




\subsection{DEFINITION OF INITIAL WASTE STREAM}

The NFBH wastes considered in this report are those expected from a central treatment facility, such as an MRS facility (or a repository receiving and handling facility), which may consolidate the spent fuel assemblies and possibly store them for a period of time before they are disposed of in a geologic repository. The untreated waste volumes in this report represent the waste volumes as removed from the process cells of an MRS facility in the current conceptual design. The current reference process for treatment of the NFBH is shredding, and initial NFBH volume is calculated based on this process. Although some spent fuel will be consolidated in power reactor storage pools, the final volumes of waste generated should not be significantly affected.

At the MRS facility (or the repository receiving and handling facility) spent fuel assemblies are received from nuclear power plants by truck or rail and taken into a processing cell where the fuel rods are removed from the remaining fuel assembly hardware. For the conceptual design, the massive pieces of residual hardware are loaded directly into the drum, and the remaining materials are sent through a shredder to facilitate handling and to reduce their volume. This hardware is a major waste stream from the consolidation operation. During the rod removal operation, most of the rods are expected to be removed intact. However, some of the rods may have failed (or may fail during removal) and may release some spent fuel particles to the hot cell and its ventilation system and contaminate the NFBH so that it may become TRUW. Table 5.1 shows the volume and mass of NFBH anticipated from consolidation operations at the MRS facility (or repository receiving and handling facility). This report uses the volumes and weights of waste estimated for an MRS facility (Ralph M. Parsons Co., Westinghouse Electric Corp. and Golder Associates 1985) and those determined by Luksic et a1. (1986) for spent fuel hardware as a basis for estimating untreated waste volumes. The mass of material is somewhat uncertain particularly for the boiling-water reactor (BWR) assemblies, which have an estimated mass from 34 to $64 \mathrm{~kg}$ per assembly. For this report, values of $38 \mathrm{~kg} /$ assembly for pressurized water reactor (PWR) assemblies and $40 \mathrm{~kg} /$ assembiy for BWR assemblies have been used. The waste volumes have been adjusted from the 3600 MTU/yr rate used in the MRS conceptual design to a 
TABLE 5.1. Projected Annual Untreated Waste Volumes from Spent Fuel Rod Consolidation(a)

\begin{tabular}{|c|c|c|c|c|}
\hline Waste Type & $\begin{array}{l}\text { Number of } \\
\text { Assembles }\end{array}$ & $\begin{array}{l}\text { Unshredded } \\
\text { Volume }\left(m^{3}\right) \\
\end{array}$ & $\begin{array}{l}\text { Shredded } \\
\text { Volume }\left(\pi^{3}\right) \\
\end{array}$ & Mass $(\mathrm{Kg})$ \\
\hline PWR Hardware & 3330 & 610 & 141 & 127,000 \\
\hline BWR Hardware & 5280 & 415 & 235 & 211,000 \\
\hline Total & 8610 & 1025 & 375 & 338,000 \\
\hline
\end{tabular}

(a) Based on consolidation of 2500 MTU of intact fuel.

processing rate of $2500 \mathrm{MTU} / \mathrm{yr}$ for this report. Sixty percent of the spent fuel (1500 MTU/yr) is considered to be from PWR's and 40\% (1000 MTU/yr) from BWR's. 


\subsection{WASTE TREATMENT PROCESSES AND THEIR RESULTING WASTE VOLUMES}

A wide variety of treatment alternatives were reviewed previously (Ross et a1. 1986). From this review and evaluation, four major alternatives were selected for evaluation in this study and are described below. The major objectives in the treatment of the NFBH are low cost, processing safety, and acceptabie waste form quality. In this section, the treated waste volumes, the loading in canisters, and thermal heat load are calculated and the basic processes are described for each of the alternatives.

Three canister sizes are utilized to account for each of the three potential repository media. The canister sizes are based on discussions with personnel at the repository sites and represent the largest size anticipated at each site for spent fuel packaging. Canister weight was not considered to be a limit, but could become one if more shielding is needed for transportation and handling of the NFBH than for spent fuel. Additional optimization of canister size is expected in future studies. The large canister sizes are expected to minimize the disposal costs.

The spreadsheets for calculation of the treated waste volumes and other characteristics generaliy show three-place accuracy, but the precision of the input data is nearer one place (10 to 20\%), depending on the specific data. Three significant figures are shown to avoid further loss of precision in subsequent calculations.

Figure 6.1 depicts the overall NFBH processing and handling. The block labeled "Treatment" represents the different treatment alternatives discussed in the Subsections 6.1 through 6.4. Operations such as assay, inspection, decontamination, and welding are considered to be treatment and are common to all of the treatment alternatives. However, the volumes of waste that will require processing through the operations will depend strongly on the treatment alternative selected.

\subsection{SHREDDING ALTERNATIVE (MRS REFERENCE)}

This alternative duplicates the treatment currently planned for the proposed MRS facility except that the MRS conceptual design has a shredder in 


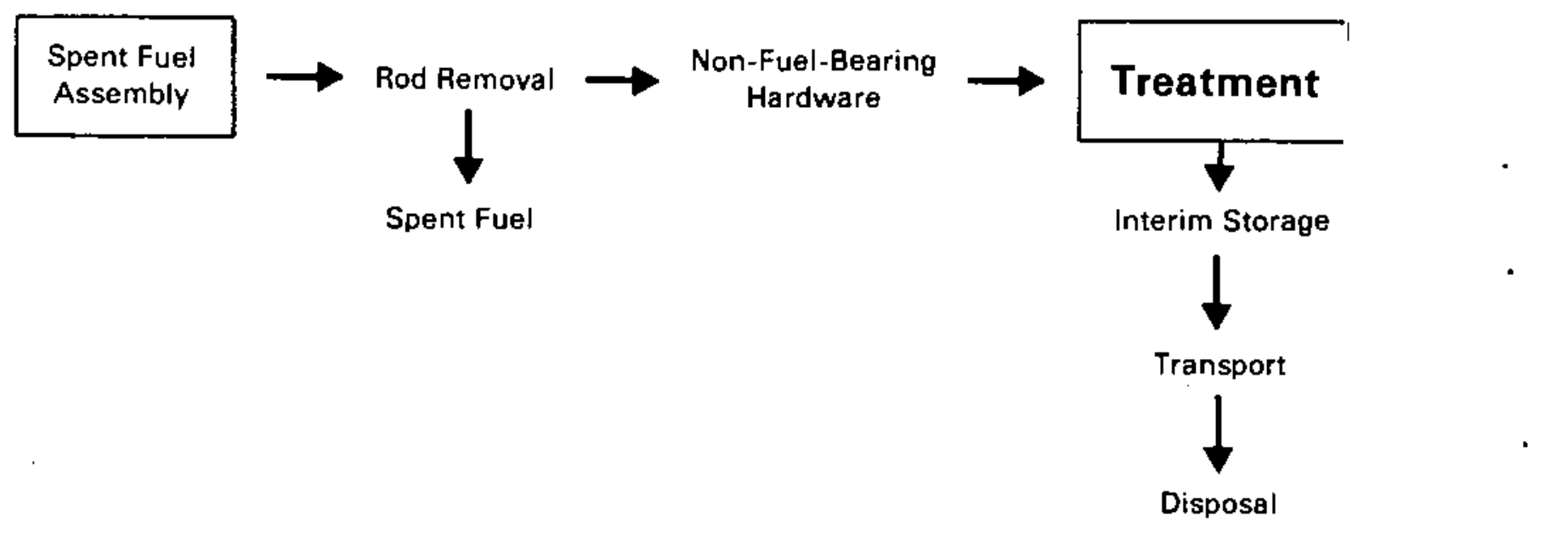

FIGURE 6.1. Treatment of NFBH in the Disposal Process

each of the four processing cells (Ralph M. Parsons Co., Westinghouse Electi"ic Corp., and Golder Associates 1985). For consistency, we have considered that: all of the processing will be done in two shredders adjacent to each pair o: consolidation cells. This decision requires removal of the NFBH from the consolidation cells to the treatment areas for all alternatives. Shredding woll d be basically a one step process. The NFBH would be removed from the cell to the shredder. Shredding the metal pieces would allow them to fit in the callisters and would increase their bulk density. The shredded NFBH would then be loaded into an appropriateiy sized canister. The shredded NFBH would have it low-bulk density of about $900 \mathrm{~kg} / \mathrm{m}^{3}$, but would still occupy significantly less volume than the untreated NFBH. The calculated annual volume of treated material is shown in Table 6.1 along with the thermal power generation rate datis.

\subsection{SHREDDING AND LOW-PRESSURE COMPACTION ALTERNATIVE}

For this alternative the shredded material would be subsequentiy compasted with a low-pressure compactor at a pressure of about $7 \mathrm{MPa}$. The low-pressu:e compactor would be located near the shredder so that successive batches of shredded NFBH would be added to the same canister after successive compaction cycles. Compaction will further reduce the volume and increase the density of the NFBH in the canister. The final bulk density is estimated to be about $1800 \mathrm{~kg} / \mathrm{m}^{3}$. Table 6.2 gives the volume, heat, and canister data for this 
TABLE 6.1. Annual Waste Volumes for Shredded NFBH $(a, b)$

\begin{tabular}{|c|c|c|c|c|c|c|}
\hline $\begin{array}{c}\text { Repository } \\
\text { Canister } \\
\end{array}$ & $\begin{array}{l}\text { Canister } \\
\text { Volume } \\
\left(m^{3}\right) \\
\end{array}$ & $\begin{array}{l}\text { Canister } \\
\text { Weight }(\mathrm{d}) \\
(\mathrm{kg}) \\
\end{array}$ & $\begin{array}{c}\text { Number } \\
\text { of PWR } \\
\text { Canisters } \\
\end{array}$ & $\begin{array}{l}\text { Therma) } \\
\text { Power } \\
\text { (watts) } \\
\end{array}$ & $\begin{array}{c}\text { Number } \\
\text { of BWR } \\
\text { Canisters } \\
\end{array}$ & $\begin{array}{c}\text { Therma } 1 \\
\text { Power } \\
\text { (watts) } \\
\end{array}$ \\
\hline Basalt & 1.31 & 1180 & 116 & 387 & 203 & 41 \\
\hline Tuff & 1.44 & 1290 & 106 & 424 & 185 & 45 \\
\hline Salt & 1.27 & 1140 & 120 & 374 & 209 & 40 \\
\hline
\end{tabular}

(a) Based on $1500 \mathrm{MTU} / \mathrm{yr}$ of PWR spent fuel and $1000 \mathrm{MTU} / \mathrm{Yr}$ of BWR spent fuel. Heat generation at 10 years out of reactor from ORIGEN2 with 33,000 MWD/MTU for PWR's and 28,000 MWD/MTU for BWR's.

(b) Data shown to three significant figures, which are maintained for the calculation but exceed the accuracy of the data.

(c) Based on canister diameters of 63,66 , and $62 \mathrm{~cm}$, respectively, and a canister length of 4.20 meters.

(d) For PWR spent fuel - weight of $38 \mathrm{~kg} /$ assembly and 0.462 assembiies per MTU. For BWR spent fuel - weight of $40 \mathrm{~kg} /$ assembly and 0.186 assemblies per MTU. Canisters filled to 90\% of capacity.

TABLE 6.2. Annual yaste Volumes for Shredded and Low-Pressure Compacted

\begin{tabular}{|c|c|c|c|c|c|c|}
\hline $\begin{array}{c}\text { Repository } \\
\text { Canister } \\
\end{array}$ & $\begin{array}{l}\text { Canister } \\
\text { Volume }(c) \\
\left(m^{3}\right)\end{array}$ & $\begin{array}{l}\text { Canister } \\
\text { Weight of } \\
\text { NFBH(d) } \\
(\mathrm{kg})\end{array}$ & $\begin{array}{c}\text { Number } \\
\text { of PWR } \\
\text { Canisters } \\
\end{array}$ & $\begin{array}{c}\text { Thermal } \\
\text { Power } \\
\text { (watts) }\end{array}$ & $\begin{array}{c}\text { Number } \\
\text { of BWR } \\
\text { Canisters } \\
\end{array}$ & $\begin{array}{c}\text { Thermal } \\
\text { Power } \\
\text { (watts) } \\
\end{array}$ \\
\hline Basalt & 1.31 & 2360 & 58 & 773 & 101 & 82 \\
\hline Tuff & 1.44 & 2590 & 53 & 849 & 92 & 90 \\
\hline Salt & 1.27 & 2280 & 60 & 749 & 105 & 79 \\
\hline
\end{tabular}

(a) Based on 1500 MTU/yr of PWR spent fuel and 1000 MTU/yr of BWR spent fuel. Heat generation at 10 years out of reactor from ORIGEN2 with 33,000 MWD/MTU for PWR's and 28,000 MWD/MTU for BWR's.

(b) Data shown to three significant figures, which are maintained for the calculation but exceed the accuracy of the data.

(c) Based on canister diameters of 63,66 , and $62 \mathrm{~cm}$, respectively, and a canister length of 4.20 meters.

(d) For PWR spent fuel - weight of $38 \mathrm{~kg} /$ assembly and 0.462 assemblies per MTU. For BWR spent fuel - weight of $40 \mathrm{~kg} / \mathrm{assembly}$ and 0.186 assemblies per MTU. Canisters filled to $90 \%$ of capacity. 
alternative. Remote compactors have been used to reduce the volume of solid LLW from power reactors for several years (Butler 1984 ).

\subsection{SHREDDING AND SUPERCOMPACTION ALTERNATIVE}

Supercompaction provides high-volume reduction of wastes without extensive treatment. It is similar to low-pressure compaction except that it uses pressures of about $60 \mathrm{MPa}$, which increases the final bulk density of the $\mathrm{NFBH}$ to about $3700 \mathrm{~kg} / \mathrm{m}^{3}$. However, the compacted steel drums would increase the weight by about $15 \%$ and the actual density would be about $4300 \mathrm{~kg} / \mathrm{m}^{3}$. Higher densities of individual compacts of simulated spent full hulls have been reported recently (Kraemer 1986). Packaged densities are lower because of clearance requirements within the canisters. Supercompaction is being used for the treatment of low-level wastes in both the U.S. and Europe (Hollo and White 1985; Sathrum and Stember 1985). The supercompactor is a massive piece of equipment that will require mechanical maintenance and may require additional cell space (not considered in this report) for interim storage of compacts before loading them into the canister.

For this analysis the wastes were preshredded and placed in 208-liter (55-gal) drums to prepare them for supercompaction. Other alternatives, such as cutting the hardware into smaller acceptable-iength sections, could also be utilized. The resulting weight, number of canisters, and their heat loads are shown in Table 6.3 .

\subsection{MELTING ALTERNATIVE}

The melting alternative provides the highest possible volume reduction for the NFBH. However, heating of the metals to high temperatures is required. The melting point of the mixed-metal NFBH is lower than those of the individual a 1 loys because new eutectics are formed. For example, an $85 \% \mathrm{Zr}$ and $15 \% \mathrm{Fe}$ mixture (the eutectic) has a melting point of $948^{\circ} \mathrm{C}$, whereas the melting point of pure $\mathrm{Zr}$ is $1852^{\circ} \mathrm{C}$ and the melting point of pure $\mathrm{Fe}$ is $1538^{\circ} \mathrm{C}$. The lower melting temperatures reduce the process temperature and should reduce the vaporization rate of radionuclides. The melting system design is expected to allow the whole residual assembly to be moved into the melter chamber, slowly 

TABLE 6.3. Annual Waste volumes for Shredded and Supercompacted
NFBH

\begin{tabular}{|c|c|c|c|c|c|c|}
\hline $\begin{array}{c}\text { Repository } \\
\text { Canister } \\
\end{array}$ & $\begin{array}{c}\text { Canister } \\
\text { Voluge }(c) \\
\left(m^{3}\right)\end{array}$ & $\begin{array}{l}\text { Canister } \\
\text { Weight of } \\
\text { NFBH(d) } \\
\text { (kg) }\end{array}$ & $\begin{array}{c}\text { Number } \\
\text { of PWR } \\
\text { Canisters } \\
\end{array}$ & $\begin{array}{l}\text { Thermal } \\
\text { Power } \\
\text { (watts) }\end{array}$ & $\begin{array}{c}\text { Number } \\
\text { of BWR } \\
\text { Canisters } \\
\end{array}$ & $\begin{array}{c}\text { Thermal } \\
\text { Power } \\
\text { (watts) } \\
\end{array}$ \\
\hline Basalt & 1.31 & 4870 & 28 & 1600 & 49 & 169 \\
\hline Tuff & 1.44 & 5340 & 23 & 1950 & 40 & 206 \\
\hline $\mathrm{Sa}+\mathrm{t}$ & 1.27 & 4720 & 29 & 1550 & 51 & 164 \\
\hline
\end{tabular}

(a) Based on $1500 \mathrm{MTU} / \mathrm{yr}$ of PWR spent fuel and $1000 \mathrm{MTU} / \mathrm{yr}$ of BWR spent fuel. Heat generation at 10 years out of reactor from ORIGEN2 with 33,000 MWD/MTU for PWR's and 28,000 MWD/MTU for BWR's.

(b) Data shown to three significant figures, which are maintained for the calculation but exceed the accuracy of the data.

(c) Based on canister diameters of 63,66 , and $62 \mathrm{~cm}$, respectively, and a canister length of 4.20 meters.

(d) For PWR spent fuel - weight of $38 \mathrm{~kg} /$ assembly and 0.462 assemblies per MTU. For BWR spent fuel - weight of $40 \mathrm{~kg} / \mathrm{assembly}$ and 0.186 assemblies per MTU. Canisters filled to $90 \%$ of capacity.

lowered into the melting crucible, and melted. Thus, shredding and its associated problems would be avoided and no additional drum material is added to the waste volume.

The development of the melting process has been under way for several years for different types of metallic waste (Westsik et a1. 1986). The process appears very applicable to the NFBH. The molten metal can be cast into any of the waste canisters on a batch or continuous basis.

The volume reduction of the melted materials is high enough that concerns about the thermal power of the canister, its weight, and radiation doses must be considered. The calculated weights, number of canisters, and the projected heat generation rates are shown in Table 6.4 .

Since the repository handling system is designed to handle the heavy overpacks for spent fuel, it should be capable of handling the heavy metal 
TABLE 6.4. Annual waste Volumes for Melted $\operatorname{NFBH}(a, b)$

\begin{tabular}{|c|c|c|c|c|c|c|}
\hline $\begin{array}{c}\text { Repository } \\
\text { Canister }\end{array}$ & $\begin{array}{c}\text { Canister } \\
\text { Volume }(c) \\
\left(m^{3}\right)\end{array}$ & $\begin{array}{l}\text { Canister } \\
\text { Weight of } \\
\text { NFBH(d) } \\
\text { (kg) }\end{array}$ & $\begin{array}{c}\text { Number } \\
\text { of PWR } \\
\text { Canisters }\end{array}$ & $\begin{array}{c}\text { Thermal } \\
\text { Power } \\
\text { (watts) } \\
\end{array}$ & $\begin{array}{c}\text { Number } \\
\text { of BWR } \\
\text { Canisters } \\
\end{array}$ & $\begin{array}{c}\text { Thermal } \\
\text { Power } \\
\text { (watts) }\end{array}$ \\
\hline Basalt & 1.31 & 6680 & 21 & 2200 & 36 & 232 \\
\hline Tuff & 1.44 & 9340 & 13 & 3400 & 23 & 360 \\
\hline Salt & 1.27 & 8240 & 17 & 2700 & 29 & 286 \\
\hline
\end{tabular}

(a) Based on 1500 MTU/yr of PWR spent fuel and 1000 MTU/yr of $8 W R$ spent fuel. Heat generation at 10 years out of reactor from ORIGEN2 with 33,000 MWD/MTU for PWR's and 28,000 MWD/MTU for BWR's.

(b) Data shown to three significant figures, which are maintained for the calculation but exceed the accuracy of the data.

(c) Based on canister diameters of 63,66 , and $62 \mathrm{~cm}$, respectively, and a canister length of 4.20 meters.

(d) For PWR spent fuel - weight of $38 \mathrm{~kg} /$ assembly and 0.462 assemblies per MTU. For BWR spent fuel - weight of $40 \mathrm{~kg} / \mathrm{assembly}$ and 0.186 assemblies per MTU. Canisters filled to $90 \%$ of capacity.

canisters also. The weight of the melted metal is calculated to be within about $20 \%$ of the weight of the spent fuel in the same size canisters without overpacks.

The heat loading for the NFBH is significantly lower than the spent fuE 1 heat generation rate. For comparisons, the heat generation rate of melted fliR NFBH is about half that of the consolidated spent fuel for the same canister size. The heat generation rate becomes a factor in the loadings of shippins casks and in the repository. Heat loadings of less than $0.45 \mathrm{~kW} / \mathrm{canister} \mathrm{dc}$ not need to be considered in the arrangement and distribution of the canistars in the repository because spacings are limited by borehole integrity considerations. Only the PWR hardware has sufficient heat generation rates to be of concern. Loading of the melted NFBH in the basalt canister is limited by a $2.2 \mathrm{~kW} /$ canister thermal load limit for 10-year-old spent fuel hardware. Fut?: hardware several years older would not be impacted. This is the only canister heat-loading limitation found in this analysis. Wide variations in potential heat-generation rates in the NFBH were identified, and additional calculations should be made when heat-generation data on actual NFBH are available. 


\subsection{COST CONSIDERATIONS}

Cost estimates were prepared for each of the TRUW treatment alternatives studied. The cost of each of the following activities was estimated:

- construction and operation of the NFBH treatment portions of the central treatment facility, including associated service facilities and materials. (These costs are assumed to be incremental to those al ready planned for the MRS facility that is used as the reference.)

- decommission of the additional facilities

- transportation of the NFBH to the deep geologic repository

- disposal of the NFBH in a deep geologic repository.

The costs are in current dollars on an undiscounted basis. Costs for research and development, licensing, selection, and development of the repository were not included.

\subsection{COST OF NFBH TREATMENT FACILITIES}

The capital and operating costs were estimated for the NFBH treatment facilities (incremental to the main parts of the MRS facility) for each alternative studied. It was assumed that the MRS facility will process 62,000 MTU of spent fuel at the rate of $2,500 \mathrm{MTU} / \mathrm{yr}$ for 25 years. The MRS facility will process the internally generated NFBH (from spent fuel consolidation) and the incoming NFBH from at-reactor consolidation of spent fuel for those same 25 years.

\subsubsection{Capital Costs for NFBH Treatment Facilities}

The capital costs for NFBH treatment facilities include the costs of: 1) design and construction of the incremental treatment (including assay and certification) facility and associated service areas, 2) purchase and installation of the equipment to process the wastes, and 3) provision of a storage area for the four-month interim storage of the treated wastes. Costs for front-end facilities common to all alternatives are not included (e.g., receiving and handling). 
The capital cost estimates (Table 7.1) for this study are based on general unit factors (Ross et al. 1986, Appendix B). Costs were estimated for mainline treatment equipment for the capacity of interest, with factors applied for modification for radioactive application and installation. Based on the overall size of the equipment, space requirements were estimated for the mainline equipment with allowances for access, accessory equipment, piping, wiring, controls, in-plant transport equipment, and short-term in-line lag storage. Volume-based unit factors were then used to estimate cell or process room facility and service facility costs.

The capital cost for all alternatives is modest at most, ranging from about $\$ 11 \mathrm{M}$ to $\$ 22 \mathrm{M}$. The four months of lag storage and the assay facilities for treated waste comprise the predominant cost element for the alternatives with little or no volume reduction (Alternatives 1 and 2), but these costs are a small fraction of the total capital costs for the alternatives with significant volume reduction (Alternatives 3 and 4 ). The more extensive treatment processes require the greater equipment and facility capital costs.

\subsubsection{Operating Costs for NFBH Treatment Facilities}

The operating costs include all the labor, maintenance, utilities, canisters, all other materials, and occasional facility upgrading for operating the incremental NFBH treatment facility and associated service areas. These operating costs are for the respective incremental facilities for which the capital cost estimates were presented in the preceding subsection (7.1.1). The

\section{TABLE 7.1. Capital Costs for NFBH Treatment Alternatives}

\begin{tabular}{|c|c|c|c|c|}
\hline \multirow[b]{2}{*}{ Cost Element } & \multirow[b]{2}{*}{ Shredding } & \multicolumn{3}{|c|}{ Cost in $\$ M(a)$} \\
\hline & & $\begin{array}{c}\text { Low-Pressure } \\
\text { Compaction }\end{array}$ & Supercompaction & Meltinc \\
\hline Treatment Facility & 1.9 & 5.3 & 15.6 & 20.2 \\
\hline Storage Facility & 10.3 & 5.9 & 3.3 & 2.1 \\
\hline Tota 1 & 12.2 & 11.2 & 18.9 & 22.3 \\
\hline
\end{tabular}

(a) Values are shown in more significant figures than the accuracy of the data to maintain consistency of the calculations. 
operating cost estimates are based on fractions of the capital costs for the various process and handling steps, as developed by Ross et al. (1986). The fractions were derived from analysis of the costs in other studies (U.S. DOE 1979; and Mckee et al. 1986). Detailed tables showing the development of operating costs are presented in Appendix A. The estimated operating costs for each alternative with the basalt canister are in Table 7.2. Similar data for the tuff and salt canisters are in Tables 7.3 and 7.4 . Operating costs are given on an annual basis and for the assumed facility operating life of 25 years.

For each alternative, the lifetime operating costs are two to five times greater than the capital costs. Canister costs are a significant part of the operating costs for each alternative and are the predominant operating costs for Alternatives 1 and 2. Canister costs are based on the costs of a Defense Waste Processing Facility (DWPF) canister with slight increases for the additional length and diameter of the proposed repository canisters. Minor differences in cost result from the difference in the number of canisters for each repository. Storage/assay costs are highest for the alternatives with the highest final waste volumes (Alternatives 1 and 2 ).

TABLE 7.2. Annual Operating Costs for NFBH Treatment Alternatives with Basalt Canisters

\begin{tabular}{|c|c|c|c|c|}
\hline \multirow[b]{2}{*}{ Cost Element } & & \multicolumn{3}{|c|}{ Cost in $\$ M(a)$} \\
\hline & Shredding & $\begin{array}{c}\text { Low-Pressure } \\
\text { Compaction }\end{array}$ & Supercompaction & Melting \\
\hline General & 0.15 & 0.42 & 1.25 & 1.62 \\
\hline Containers & 1.70 & 0.85 & 0.41 & 0.30 \\
\hline Storage \& Assay & 0.16 & 0.08 & 0.04 & 0.03 \\
\hline Annual Total & 2.02 & 1.36 & 1.70 & 1.95 \\
\hline 62,000 MTU Total & 50.0 & 33.6 & 42.1 & 48.2 \\
\hline
\end{tabular}

(a) Values are shown in more significant figures than the accuracy of the data to maintain consistency of the calculations. 
TABLE 7.3. Annual Operating Costs for NFBH Treatment Alternatives with Tuff Canisters

\begin{tabular}{|c|c|c|c|c|}
\hline Cost Element & Shredding & $\begin{array}{c}\text { Low-Pressure } \\
\text { Compaction }\end{array}$ & Supercompaction & Meltins: \\
\hline General & 0.15 & 0.42 & 1.25 & 1.62 \\
\hline Containers & 1.58 & 0.79 & 0.34 & 0.20 \\
\hline Storage \& Assay & 0.15 & 0.07 & 0.03 & 0.02 \\
\hline Annual Total & 1.88 & 1.28 & 1.62 & 1.84 \\
\hline 62,000 MTU Total & 46.7 & 31.9 & 40.3 & 45.4 \\
\hline
\end{tabular}

(a) Vaiues are shown in more significant figures than the accuracy of the data to maintain consistency of the calculations.

TABLE 7.4. Annual Operating Costs for NFBH Treatment Alternatives with Salt Canisters

\begin{tabular}{|c|c|c|c|c|}
\hline Cost Element & Shredding & $\begin{array}{l}\text { Low-Pressure } \\
\text { Compaction }\end{array}$ & Supercompaction & Melting \\
\hline General & 0.15 & 0.42 & 1.25 & 1.62 \\
\hline Containers & 1.75 & 0.87 & 0.43 & 0.25 \\
\hline Storage \& Assay & 0.17 & 0.08 & 0.04 & 0.02 \\
\hline Annual Total & 2.07 & 1.37 & 1.72 & 1.89 \\
\hline 62,000 MTU Total & 51.3 & 34.2 & 42.5 & 46.8 \\
\hline
\end{tabular}

(a) Values are shown in more significant figures than the accuracy of the data to maintain consistency of the calculations.

\subsubsection{Summary of NFBH Facility Costs}

The life-cycie capital and operating costs and the decommissioning costs for the incremental treatment facility with basalt, tuff, and salt canisters are summarized in Figure 7.1 , which shows the dominance of the operating cos:5 in the total lifetime costs of the incremental NFBH treatment facility. Differences with type of repository canister are less than $10 \%$ and are directly related to the cost and number of canisters. Decomissioning costs, which ane 


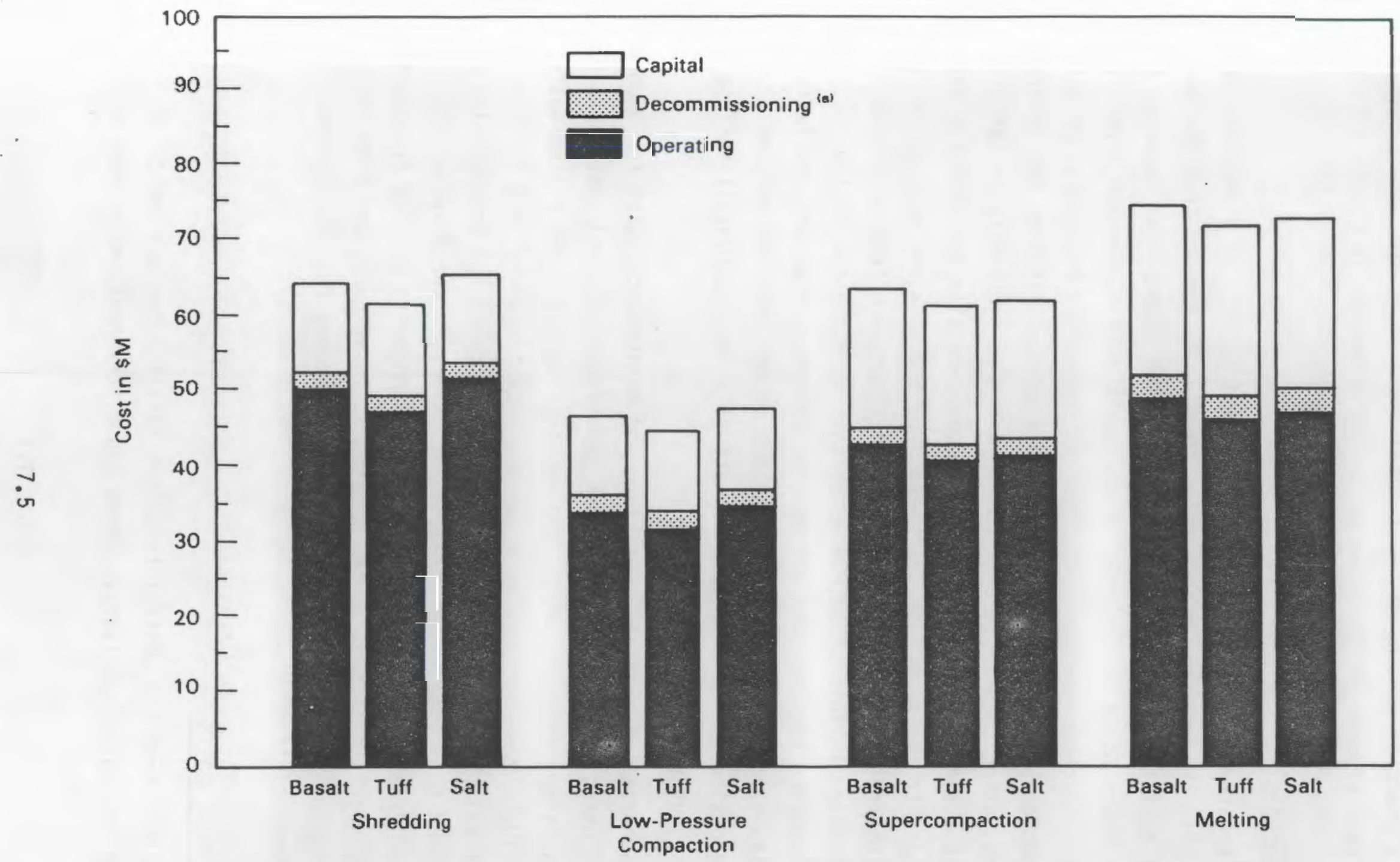

(a)Decommissioning costs are taken to be $12 \%$ of capital cost per DOE 1986.

FIGURE 7.1. Lifetime (62,000 MTU) Capital, Operating, and Decommissioning Costs of NFBH Treatment Alternatives 
based on a fraction of the initial capital costs (U.S. DOE 1986), are the smallest cost element of the three major cost elements in Figure 7.1 .

\subsection{TRANSPORTATION COSTS}

The treated NFBH is assumed to be shipped by rail to a deep geologic repository in the western United States that is 2000 miles from the central treatment facility located in the eastern United States. No separate transportation costs would be incurred if the spent fuel is shipped directly to repository for consolidation. The $\mathrm{NFBH}$ is assumed to be shipped on a rail transportation system (U.S. DOE 1986a) owned and operated by the federal government, using five-car dedicated trains. The similarity in canister size means that a similar number of canisters can generally fit within a cask. The major limits to the number of canisters within a cask are size and weight. A maximum internal diameter of $144.8 \mathrm{~cm}$, a maximum cask load of $18,000 \mathrm{~kg}$, and a suggested thermal limit of 13,000 watts/cask were considered limits in this study. Diameter limited most of the cask loading. However, the Tuff canister with melted hardware was limited by weight to one canister per cask. A slight weight reduction in the canisters may actually improve overall tuff system economics, but was not included.

Transportation capital, operation, and maintenance costs for NFBH were estimated using the unit factors (cask capacity, 1ife, and costs; train speed; turnaround time; shipping costs; and security costs) given in the Waste Management SRD (U.S. DOE 1986a). Table 7.5 presents the annual and lifetime operating costs and the initial and lifetime capital costs for transporting the treated NFBH from the central treatment facility to the disposal facility. Details of transportation costs are given in Appendix B. The transportation costs are highly dependent on the treated waste volumes, and they exceed the total lifetime facility capital and operating costs for the alternatives with high volumes of treated wastes (Alternatives 1 and 2 ).

\subsection{DISPOSAL COSTS}

The NFBH from the central treatment facility are assumed to be disposed of in a deep geologic repository. Three repository media have been considered in 
TABLE 7.5. Lifetime Transportation Costs for NFBH Treatment Alternatives

\begin{tabular}{|c|c|c|c|c|}
\hline \multirow[b]{2}{*}{ Type Canister } & \multicolumn{4}{|c|}{ Cost in $\$ M(a)$} \\
\hline & Shredding & $\begin{array}{l}\text { Low-Pressure } \\
\text { Compaction }\end{array}$ & Supercompaction & Melting \\
\hline Basalt & 273 & 137 & 67 & 47 \\
\hline Tuff & 250 & 129 & 52 & 64 \\
\hline Salt & 288 & 139 & 69 & 42 \\
\hline
\end{tabular}

(a) Values are shown in more significant figures than the accuracy of the data to maintain consistency of the calculations.

determining the costs. Repository surface cost data are based on results of an MRS/Repository Interface Task Force Report (DOE 1986b). Underground costs are data from a 1985 estimate of total system life cycle costs (DOE 1985). The costs have been developed for two storage arrangements: the first case assumes that the canisters of NFBH are emplaced between canisters of spent fuel with a high-quality overpack around the NFBH canister to provide long-term protection consistent with NRC requirements for spent fuel. The second case assumes that the canisters of NFBH are stored in a separate, cooler part of the repository without the need for overpacks.

In both cases, NFBH waste emplacement densities were calculated based on either limiting structural spacing for boreholes ( $2 \mathrm{~m}$ on center) or limiting areal heat loading $\left(15 \mathrm{~W} / \mathrm{m}^{2}\right.$ for basalt, $14.25 \mathrm{~W} / \mathrm{m}^{2}$ for tuff and $10 \mathrm{~W} / \mathrm{m}^{2}$ for salt). Factors were applied to certain repository costs for waste handing, overpacks (if needed), transport, and emplacement based on the ratios of number of canisters handled. Underground excavation, rock handling, and ventilation costs were factored based on the ratio of increased-area requirements. Disposal costs for both overpack alternatives are shown in Table 7.6. However, only the lower cost alternative (either no overpack or heavy overpack) is used in subsequent total life cycle cost calculations. An examination of Table 7.6 shows significant savings in disposal cost for the lower-waste-volume compaction alternatives. Costs are generally higher in basalt, because of higher rock excavation costs. One unanticipated conclusion is that costs for the low-compaction, no-overpack cases are higher than for the cases with 
TABLE 7.6. Repository Disposal Costs for NFBH Treatment Alternatives

\begin{tabular}{|c|c|c|c|c|c|c|}
\hline \multirow{3}{*}{$\begin{array}{l}\text { Compaction } \\
\text { Alternative }\end{array}$} & \multicolumn{6}{|c|}{ Cost in $\$ M(a)$} \\
\hline & & Overpa & & Witho & t Over & ack \\
\hline & Basalt & Tuff & Salt & Basalt & Tuff & Salt \\
\hline Shredding & 476 & 368 & 498 & 911 & 395 & 310 \\
\hline $\begin{array}{l}\text { Low-Pressure } \\
\text { Compaction }\end{array}$ & 298 & 208 & 274 & 450 & 198 & 155 \\
\hline Supercompaction & 215 & 116 & 156 & 221 & 86 & 94 \\
\hline Melting & 189 & 85 & 109 & 161 & 66 & 68 \\
\hline
\end{tabular}

(a) Values are shown in more significant figures than the accuracy of the data to maintain consistency of the calculations.

overpacks. For very low NFBH bulk densities and canister heat rates, the incremental spacing between spent fuel canisters required to stay within areal heat loading limits is small, and therefore additional mining costs are small for co-emplacement with spent fuel. The minimum borehole spacing required for placing non-overpacked wastes in a separate repository area results in higher space requirements and mining costs. These mining costs in hard rock media such as basalt and tuff outweigh the cost savings achieved by eliminating the overpack requirement. At high NFBH bulk densities with higher canister heat loadings this effect is reduced until (for the melting alternative) disposal is less costly with no overpack than with overpack for all repository media.

\subsection{TOTAL LIFE-CYCLE COSTS}

The total life-cycle costs (exclusive of research and development and repository siting development and engineering costs) for management of the $N=B H$ from the four treatment alternatives are given in Figure 7.2. These costs are summarized from Tables 7.1 through 7.6. For the basalt alternative, the disposal costs are the major costs. The large transportation costs for both shredding and low-pressure compaction should be noted. These costs are very similar to the disposal costs for the Tuff and Salt alternatives. 


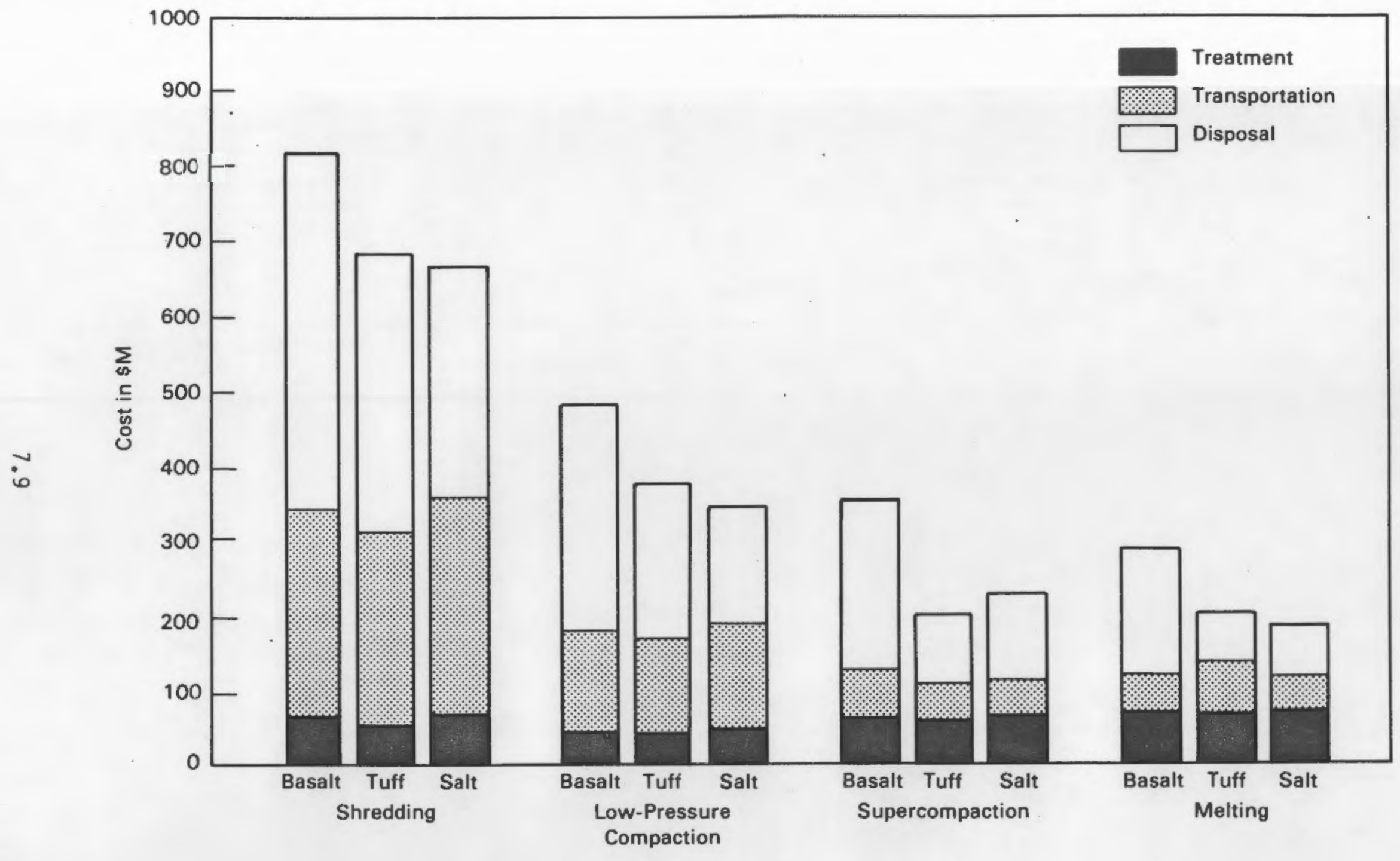

FIGURE 7.2. Lifetime (62,000 MTU) Treatment, Transportation, and Disposal Costs for NFBH Treatment Alternatives 



\subsection{WASTE FORM AND PROCESS CONSIDERATIONS}

Previous sections have emphasized the identification and evaluation of NFBH treatment alternatives based on waste volumes, packaging, and analysis of the waste management system costs. The waste form characteristics (based on waste acceptance at the repository) and the waste treatment process characteristics (operational safety, process simplicity, status of technology) are discussed and compared in this section.

\subsection{WASTE FORM CONSIDERATIONS}

The general requirements for the waste forms were reviewed in Section 4.0 with the regulatory requirements for waste disposal. Geologic disposal of the NFBH in a federal repository is assumed in this study. As noted in Section 4.0, the acceptability for disposal of any waste form cannot be stated with certainty because detailed waste form requirements have yet to be established. It follows, however, that the better the properties of the waste form, the greater the likelihood of its acceptance for disposal and the higher its rating in this evaluation. Also note that spent fuel assemblies are currently acceptable for disposal and that the assemblies contain the NFBH without any additional treatment. Therefore, any of these treatment processes should produce an acceptable waste form. As indicated in Section 4.0, the waste form may be required to have specific characteristics. The most significant characteristics are:

- low release rate of radionuclides from the waste form, especially during water contact, which is viewed as the most likely release mechanism following geologic disposal

- immobilized particulates (to avoid release of material if a canister fails during handing or transportation and to reduce potential release rates)

- no pyrophoric potential in the waste materials (important during waste package handling, transportation, and storage) 
- structural stability to assist in preventing mechanical failure of the canister, overpack, or container.

Waste property data for each type of potential waste form have not been prepared or characterized; therefore, sufficient characterization data is rot available to provide a quantitative comparison of the properties. However, from existing experience with other types of materials, the general characteristics can be anticipated. With this general experience, the four processes have been compared, and a summary is shown in Table 8.1. Note that melting will likely produce an acceptable waste form and that, depending on the establishment of the acceptance requirements, waste forms produced by the other alternatives may not be acceptable. Details of the ratings follow.

The release rate is expected to decrease with increasing density of the waste forms and should be significantly improved for the melted product. The supercompacted material would still have an open porous structure and allow ready access to leachants, but because of its higher density may provide a higher resistance to leaching than the lower-density alternatives. The compaction and melting of the NFBH should reduce the availability of the particles for release. The melted product should not have a significant number of particles, and the supercompacted particulate should be trapped within the compacted mass. Therefore, these waste forms are rated higher than the low-pressure compacted metal and the shredded meta? waste forms.

IABLE 8.1. Evaluation of Waste Form Characteristics for Process Alternatives

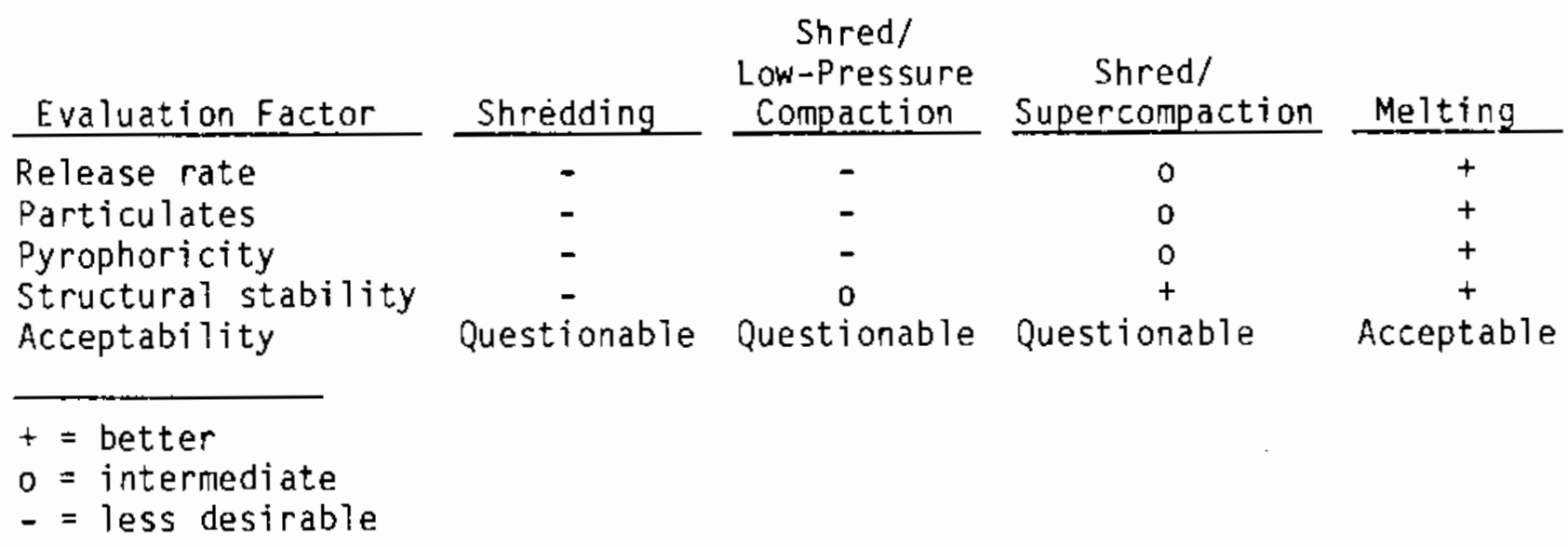


Shredding can be expected to generate some fines, and compaction may also generate some new surfaces and fines that can react with atmospheric oxygen and be slightly pyrophoric. Fines within the supercompacted mass should be less available and therefore less reactive. Because fines would be eliminated by melting, this form has the best rating.

Structural stability is mostly dependent on the void volume within the canister that may fill with backfill materials in the event of an overpack failure. Thinning of the backfill could reduce the long-term containment of the radionuclides. The waste forms have been rated in relationship to their final density.

The above analyses indicate that the melted product is most attractive and that density influences the behavior of the waste form for most of the characteristics considered.

\subsection{PROCESS CONS IDERATIONS}

The processes required for each waste treatment alternative were also evaluated qualitatively based on experience with the processes for other types of materials. A summary comparing the process characteristics of the four treatment alternatives is shown in Table 8.2. Evaluations of various aspects of operational safety, process simplicity, and technology status are presented for each alternative. As explained in the detailed comments below, the shredding alternative is preferred from a review of the processing characteristics; the melting and supercompaction alternatives need additional development before they can be utilized.

\subsubsection{Operational Safety}

Operational safety factors are subdivided into chemical hazards, fire hazards, mechanical hazards, electrical hazards, and radionuclide release. The off-gas system (as part of the melting alternative) would probably contain liquids and chemical agents and is therefore the highest chemical hazard. However, this hazard is of minor significance. The shredder and compactors do not use any chemicals and have a low hazard potential. 
TABLE 8.2. Evaluation of Process Characteristics for Treatment Alternatives

\begin{tabular}{|c|c|c|c|c|}
\hline $\begin{array}{c}\text { Process } \\
\text { Characteristics } \\
\end{array}$ & Shredding & $\begin{array}{c}\text { Shred/ } \\
\text { Low-Pressure } \\
\text { Compaction } \\
\end{array}$ & $\begin{array}{c}\text { Shred/ } \\
\text { Supercompaction }\end{array}$ & Melting \\
\hline Operational safety & Satisfactory & Satisfactory & Satisfactory & Satisfa:tory \\
\hline Chemical & + & + & + & 0 \\
\hline Fire & - & - & - & - \\
\hline Mechanical & - & - & - & + \\
\hline Electrical & + & + & + & + \\
\hline $\begin{array}{l}\text { Radionuclide } \\
\text { release }\end{array}$ & 0 & 0 & 0 & - \\
\hline Process simplicity & $\begin{array}{l}\text { Greatest } \\
\text { simplicity }\end{array}$ & Moderate & Complex & Complex \\
\hline Equipment design & + & 0 & - & - \\
\hline Operations & + & 0 & - & - \\
\hline Maintenance & + & 0 & - & - \\
\hline Technology status & Available & Available & $\begin{array}{c}\text { Some } \\
\text { development }\end{array}$ & $\begin{array}{l}\text { Developinent } \\
\text { needied }\end{array}$ \\
\hline Hot cell use & 0 & 0 & 0 & - \\
\hline Radioactive use & + & + & + & 0 \\
\hline Industrial use & + & + & - & + \\
\hline Time to implement & + & + & 0 & - \\
\hline
\end{tabular}

Fire hazards result from the generation of pyrophoric particulates, the use of combustible fluids, and operations at high temperature. The shredder has the potential for generating pyrophoric materials. The melter, operat ng at high temperatures and handling hot zirconium metal, also has potential safety concerns. Neither of these are desirable conditions.

Mechanical hazards were judged based on the degree of mechanical action. Thus, the shredder has the highest potential. Electrical hazards are related to the amount of electrical power used in the process and any significant potential problems in handling it. The shredder, supercompactor, and melter will use significant amounts of power (about 75 to $100 \mathrm{KW}$ ). However, this amount of power is not a major hazard because it can be easily handled with conventional technology. 
The radionuclide release hazard is based on the potential of release to the atmosphere. The melter has the highest potential because material will be volatilized in the melter and will have to be removed by the off-gas treatment system. The shredder and the compactors would generate some particulates (mostly "crud") that would be released to the cell. None of the hazards appear to disqualify one of the processes from satisfactory operation in remote conditions.

\subsubsection{Process Simplicity}

The three primary factors in evaluating process simplicity are equipment complexity, operational complexity, and maintenance requirements. For equipment design complexity, the shredder was judged to be the simplest, with only one step and only a feed input and a product out. Low-pressure compactors have a simple hydraulic ram and were also considered simple except that the canisters were considered to be filled and compacted in a series of successive operations. The supercompactor was judged complex because it requires an accurate drum positioner; has high-pressure hydraulics, massive rams, and dies that must resist mechanical yielding; and must be designed to remove the compacts from the dies following the extrusion of metal materials in the die. It riust also have a more complicated canister loading system to prevent overloading and to optimize the filling. The melter would have an atmospheric protection chamber to avoid oxygen in the melter chamber, a control method for the electrical power, a cooling system for the melting chamber, a method for feeding the $\mathrm{NFBH}$ into the melting region, and a method to monitor the fill in the receiving canister. However, the melting system is conceptually considered to be much smaller than the supercompactor.

Operational complexity is similar to equipment complexity. Because of the need for an atmospheric control system in the melter, it is expected to be operationally complex. The many mechanical systems of the supercompactor also make it operationally complex.

Maintenance requirements will not be known until the systems have been operated with the anticipated wastes, but the melter would likely require regular maintenance on the electrodes or heat sources. The high-pressure hydraulic 
system and the high mechanical forces used in the supercompactor are also expected to necessitate frequent maintenance.

\subsubsection{Status of Technology}

The status of technology is judged based on experience with the proces: in hot cells, radioactive service, and industrial usage, and on the time needed to implement the technology if it is selected.

The only process operation that has seen hot cell service is the off gas system. Low-pressure compactors have been used in a remote environment for reducing reactor wastes, and some installations also have supercompactors that are remotely operated. Melting and shredding have not been used in hot cel's. Low-pressure compactors have seen the greatest radioactive use outside of hot cells. Shredders have been used in limited applications and supercompactor llse is increasingly with the increased costs of low-level waste disposal. Melters have been used to treat lightly contaminated metals at both ORNL and INEL. Industrial use of the equipment provides a base of technology that can be very useful in the design and operation of the processes. Melting systems are very

common in the preparation and processing of metals. Shredding is likewise s sed heavily in industry for a wide variety of applications. Low-pressure compaction is a common technology, but supercompaction is relatively new technology.

A shredding system with or without a low-pressure compaction option colid be designed most quickly. The melter would take the longest time to implement since it needs to be designed for this application and then tested. Superconpaction, with its need for significant maintenance and process complexity, i?so requires an extended design and testing period.

\subsubsection{Summary of Process Evaluation}

The summary of process ratings in Table 8.2 shows that the shredding alternative has the greatest simplicity and is most available. These characteristics were important in its selection as the reference process for the MRS. The melting and supercompaction alternatives are more complex and will require some development time if they are selected for implementation. 


\subsection{FINAL EVALUATION OF TREATMENT ALTERNATIVE METHODS}

This section discusses the waste form characteristics from Table 8.1, process characteristics from Table 8.2, and costs from Table 7.8 for each of the alternatives. These three tables are summarized in Table 9.1, which shows that the shredding option has better process characteristics, but is higher in cost and produces a less desirable waste form than the other alternatives. Melting, however, has the lowest cost and the best waste form but the least desirable process characteristics. Supercompaction is similar in costs and process to melting and has a better waste form than shredding. Low-pressure compaction, aithough a simple technology, is more complex than shredding. It offers some cost improvement, but not as great as the savings with melting and supercompaction. Low-pressure compaction waste form characteristics are similar to those of shredding.

TABLE 9.1. Comparison of Strengths and Weaknesses of Ireatment Alternatives

\begin{tabular}{|c|c|c|}
\hline Alternative & Major Strengths & Major Concerns \\
\hline Shredding & $\begin{array}{l}\text { - Process Simplicity } \\
\text { - State of Technology }\end{array}$ & $\begin{array}{l}\text { - Pyrophoric Fines } \\
\text { - Low Bulk Density } \\
\text { - High System Costs }\end{array}$ \\
\hline $\begin{array}{l}\text { Low-Pressure } \\
\text { Compaction }\end{array}$ & $\begin{array}{l}\text { - Simple Technology } \\
\text { - Significant Volume } \\
\text { Reduction } \\
\text { - Remote Experience }\end{array}$ & $\begin{array}{l}\text { - Pyrophoric Fines } \\
\text { - Low Bulk Density } \\
\text { - High System Costs }\end{array}$ \\
\hline Supercompaction & $\begin{array}{l}\text { - High Volume Reduction } \\
\text { - Low System Costs } \\
\text { - Better Waste Form } \\
\text { Properties }\end{array}$ & $\begin{array}{l}\text { - Mechanically Complex } \\
\text { - High Potential Maintenance } \\
\text { - Limited Remote Experience } \\
\text { - No Destruction of Organic } \\
\text { materials }\end{array}$ \\
\hline Melting & $\begin{array}{l}\text { - Low System Costs } \\
\text { - Best Waste Form } \\
\text { Properties } \\
\text { - No Fines Generation } \\
\text { - Highest Volume } \\
\text { Reduction } \\
\text { - Few Mechanical Parts }\end{array}$ & $\begin{array}{l}\text { - High Temperature Operation } \\
\text { - Atmospheric Control Needed } \\
\text { - Need Technology Demonstration } \\
\text { - Maintenance of Electrodes and } \\
\text { Crucibles } \\
\text { - Coolants Needed }\end{array}$ \\
\hline
\end{tabular}


Any of the four alternatives provide for the treatment of the NFBH. However, the selection should take into consideration all of the comparative strengths and weaknesses. Both melting and supercompaction have major strengths that need to be better defined. A testing program would provide more detailed information upon which to make a final selection. 


\section{REFERENCES}

Butler, C. N., F. Fejzollahi, T. B. Janbue. 1984. "Low-Level Dry Active Waste Management Planning for Calvent Cliffs Nuclear Power Plant. In Proceedings of Waste Management '84. Vol. 2 p. 307. University of Arizona, Tucson, Arizona, pp. 383-393.

Hollo, P. and R. G. White. 1985. "Preparing for High-Tonnage Press Processing Options." In Proceedings of Incineration of Low Level Wastes. Tucson, Arizona.

Kraemer, R., H. Frotscher, H. Grabner, and H. Kapilla. 1986. "The Management of Cladding Hulls and Fuel Hardware." In Proceedings of Spectrum '86. Niagara Falls, New York.

Luksic, A. T., R. W. Mckee, P. M. Dailing, G. J. Konzek, J. D. Ludwick, and W. L. Purcel1. 1986. Spent Fuel Disassembly Hardware and 0ther Non-Fuel Bearing Components: Characterization, Disposal Cost Estimates, and Proposed Repository Acceptance Requirement. PNL-6046, Pacific Northwest Laboratory, Richland, washington.

Mckee, R. W., et a1. 1986. Waste Management System Alternatives for Treatment of Wastes from Spent Fuel Reprocessing. PNL-6005, Pacific Northwest

Laboratory, Richland, Washington.

Ralph M. Parsons Co., Westinghouse Electric Corps. and Golder Associates. 1985. Integral Monitored Retrievable Storage (MRS) Facility Conceptual Design Report. Ralph M. Parsons Co., Pasadena, California.

Ross, W. A., K. J. Schneider, K. H. Oma, R. I. Smith, and L. R. Bunnell. 1986. Evaluation of Alternative Treatments for Spent Fuel Rod Consolidation Wastes and Other Miscellaneous Commercial Transuranic Wastes. PNL-5838, Pacific Northwest Laboratory, Richland, Washington.

Sathrum, C. H. and D. L. Stember. 1985. "Volume Reduction of Dry Active Wastes by a Mobile Supercompactor System." In Proceedings of Incineration of Low-Level Wastes, Tucson, Arizona.

Transuranic Waste Systems 0ffice. 1983. TRU Waste Certification Compliance Requirements for Contact-Handled Wastes Retrieved from Storage for Shipment to the Wipp. WIPP-D0E-137. Rocky Flats Plant, Golden, Colorado.

U.S. Department of Energy. 1979. Technology for Commercial Radioactive Waste Management. DOE/ET-0028, 5 volumes, U.S. Department of Energy, Washington, D.C.

U.S. Department of Energy. 1985. Analysis of the Total System Life Cycle Cost for the Civilian Radioactive Waste Program, prepared by Roy F. Weston, Inc., DOE/RW-0025, U.S. Department of Energy, Washington, D.C. 
U.S. Department of Energy. 1986a. Waste Management System Requirements and Descriptions (SRD). D0E/RW-0063, U.S. Department of Energy, Washington, D.C. i.e., Classification, 10 CFR Section 61.55 (1986).

U.S. Department of Energy. 1986b. Report of the Task Force on the MRS/Repository Interface. DOE/RW-0044, U.S. Department of Energy, Washington, D.C.

U.5. Department of Energy. 1986c. "Waste Acceptance Preliminary Specifications for the Defense Waste Processing Facility High Level Waste Form." OGR/B-8 (Draft), Washington, D.C.

U.S. Nuciear Regulatory Commission. 1983. Federal Register. Vol 48, \#120, June $21,1983$.

Westsik, J. H., Jr., D. R. Montgomery, Y. B. Katayama, and W. A. Ross. 1986. "Induction Melting for Volume Reduction of Metallic TRU Wastes." In Proceedings of Waste Management 1986. University of Arizona, Tucson, Arizona. 
APPENDIX A

TREATMENT COSTS FOR NFBH TREATMENT ALTERNATIVES 
APPENDIX A

TREATMENT COSTS FOR NFBH TREATMENT ALTERNATIVES

The details of estimated equipment and facility storage costs, operating costs, and transportation costs are described below.

\section{A.1 TREATMENT FACILITY CAPITAL COSTS}

The facility capital costs are detailed in Table A.1. The major assumptions include the assumption that the installation costs for the remote equipment, which include the costs for adaptation for remote radioactive operations, is equal to the cost of the equipment itself. The volumes of the cells are estimated based on the size of the process equipment and the needed space around the process equipment to allow operation and maintenance activities within the cells. The basic hot cell costs are estimated at $\$ 5,300 / \mathrm{m}^{3}$ $\left(\$ 150 / \mathrm{ft}^{3}\right)$. An additional cost for galleries is included. The gallery volumes are assumed to be two times the cell volume and are estimated to cost $\$ 880 / \mathrm{m}^{3}$ $\left(\$ 25 / \mathrm{ft}^{3}\right)$. Therefore, the total cost for cell and gallery is $\$ 7,100 / \mathrm{m}^{3}$ $\left(\$ 200 / \mathrm{ft}^{3}\right)$ based on the hot-celi volume. Indirect costs for engineering (15\%), overheads and fees (35\%), contract administration (3\%) and contingency (25\%) totaled $78 \%$ of the direct costs. These indirect costs are added to get the total cost (last column of Table A.1) for each of the processes. The indirect costs are also totaled for each of the alternatives.

The interim storage capital costs are shown in Table A.2. These costs are directly related to the total volume of the packaged waste. The basic assumption used in determining the costs are that the cell space required is equal to nine times the volume of the waste. This allows for some space around the canisters for cooling air and overhead crane access. The values calculated from this are shown in the column titled "unscaled storage costs." The relative storage costs were also calculated based on an 0.8 power scaling factor and the relative volumes with 416 cubic meters as the reference volume. 
TABLE A.1. Facility and Equipment Capital Costs (a)

\begin{tabular}{|c|c|c|c|c|c|c|c|c|c|}
\hline Process & Equipment & $\begin{array}{l}\text { Equi pment, } \\
\text { SThousands }\end{array}$ & $\begin{array}{l}\text { Installation, } \\
5 \text { Thousands } \\
\end{array}$ & $\begin{array}{c}\text { Hot Cell } \\
\text { voluge, } \\
\mathrm{ft}\end{array}$ & $\begin{array}{c}\text { Constr. } \\
\text { cost. } \\
\text { s/ft+ }\end{array}$ & $\begin{array}{c}\text { Total } \\
\text { Constr., } \\
\text { s Thoussands } \\
\end{array}$ & $\begin{array}{r}\text { Direct } \\
\text { Costs, } \\
\text { Shousands } \\
\end{array}$ & $\begin{array}{c}\text { Indirect } \\
\text { Costs, } \\
\$ \text { Thousands } \\
\end{array}$ & $\begin{array}{c}\text { Total } \\
\text { Costs, } \\
\text { Ithousands } \\
\end{array}$ \\
\hline Shredding & Shredder & 240 & 240 & 3,000 & 200 & 600 & $t, 080$ & 0.78 & 1,920 \\
\hline \multirow[t]{2}{*}{$\begin{array}{l}\text { Low-Pressure } \\
\text { Compaction }\end{array}$} & $\begin{array}{l}\text { Shredder } \\
\text { Drum Compactor }\end{array}$ & $\begin{array}{r}240 \\
148 \\
\end{array}$ & $\begin{array}{r}240 \\
148 \\
\end{array}$ & $\begin{array}{r}3,000 \\
8,000 \\
\end{array}$ & $\begin{array}{l}200 \\
\underline{200} \\
\underline{-1}\end{array}$ & $\begin{array}{r}600 \\
1,600 \\
\end{array}$ & $\begin{array}{l}1,080 \\
1,896 \\
\end{array}$ & $\begin{array}{l}0.78 \\
0.78 \\
\end{array}$ & $\begin{array}{l}1,920 \\
3,380 \\
\end{array}$ \\
\hline & Total & 388 & 388 & 11,000 & & 2,200 & 2,980 & & 5,300 \\
\hline \multirow[t]{2}{*}{ Super compactlon } & $\begin{array}{l}\text { Shredder } \\
\text { Supercompactor }\end{array}$ & $\begin{array}{r}240 \\
2,800 \\
\end{array}$ & $\begin{array}{r}240 \\
2,800 \\
\end{array}$ & $\begin{array}{r}3,000 \\
10,400 \\
\end{array}$ & $\begin{array}{r}200 \\
200 \\
\end{array}$ & $\begin{array}{r}500 \\
2,080 \\
\end{array}$ & $\begin{array}{l}1,080 \\
7,580 \\
\end{array}$ & $\begin{array}{l}0.78 \\
0.78 \\
\end{array}$ & $\begin{array}{r}1,920 \\
13,700 \\
\end{array}$ \\
\hline & Total & 3,040 & 3,040 & 13,400 & & 2,680 & 8,760 & & 15,600 \\
\hline \multirow[t]{2}{*}{ Melting } & $\begin{array}{l}\text { Induction Melter } \\
\text { off Gas System }\end{array}$ & $\begin{array}{l}1,600 \\
:, 700 \\
\end{array}$ & $\begin{array}{l}1,600 \\
1,700 \\
\end{array}$ & $\begin{array}{l}10,400 \\
13,400 \\
\end{array}$ & $\begin{array}{l}200 \\
200 \\
\end{array}$ & $\begin{array}{l}2,080 \\
\underline{2,680} \\
\end{array}$ & $\begin{array}{r}5,280 \\
6,080 \\
\end{array}$ & $\begin{array}{l}0.78 \\
0.78 \\
\end{array}$ & $\begin{array}{r}9,400 \\
10,800 \\
\end{array}$ \\
\hline & Total & 3,300 & 3,300 & 23,800 & & 4,760 & 11,360 & & 20,200 \\
\hline
\end{tabular}

(a) Values are shown 1 m more significant figures than the accuracy of the data to maintaln consistency in the calculatlons. 
TABLE A.2. Four-Month Interim Storage Costs (a)

\begin{tabular}{|c|c|c|c|c|c|}
\hline Process & $\begin{array}{c}\text { Packaged } \\
\text { Volume in } \\
\text { Canisters } \\
\mathrm{m}^{3} / \mathrm{yr} \\
\end{array}$ & $\begin{array}{l}\text { Cel1 } \\
\text { Space, } \\
\mathrm{ft}^{3}(\mathrm{~b}) \\
\end{array}$ & $\begin{array}{c}\text { Unscaled } \\
\text { Storage } \\
\text { Costs, } \\
\$ \text { Thousands } \\
\end{array}$ & $\begin{array}{c}\text { Scaled } \\
\text { Storage } \\
\text { Costs, } \\
\$ \text { Thousands } \\
\end{array}$ & $\begin{array}{c}\text { Total } \\
\text { Capital } \\
\text { Costs, } \\
\text { \$housands } \\
\end{array}$ \\
\hline Shredding & 416 & 33,076 & 10,287 & 10,287 & 12,209 \\
\hline $\begin{array}{l}\text { Low-Pressure } \\
\text { Compaction }\end{array}$ & 208 & 16,538 & 5,143 & 5,908 & 11,205 \\
\hline Supercompaction & 101 & 8,012 & 2,492 & 3,309 & 18,902 \\
\hline Melting & 58 & 4,591 & 1,428 & 2,119 & 22,340 \\
\hline
\end{tabular}

(a) Vaives are shown in more significant figures than the accuracy of the data to maintain consistency in the calculations.

(b) Cell space at nine times the four-month canister volume.

(c) Storage costs at $\$ 311 / \mathrm{ft}^{3}=150$ (cel1) + 25 (gallery) times 1.78 factor.

(d) Scaled costs based on shredding only with others at 0.8 power on volume.

These values are shown in the column titled "scaled storage costs." The total capital costs are then shown in the last column.

\section{A.2 TREATMENT FACILITY OPERATING COSTS}

The derivations of the annual operating costs for the alternatives are shown in Tables A.3 through A.5 for basalt, tuff, and salt disposal, respectively. The annual costs are comprised of three major types of costs: 1) cost of operation (i.e., manpower), 2) cost of containers, and 3) cost of assay, storage, and certification of the waste containers. These costs are grouped in Tables A.3 through A.5 and then totaled. Basic operating costs are taken to be a fraction of the capital costs. The fraction was selected based on the degree of operator supervision required for the process. Simple processes such as cementing are taken to be $4 \%$ of the capital costs. Typically, $8 \%$ of the capital costs are used as an estimate of the annual operating costs. However, annual costs of processes such as separation of wastes into components are taken as $10 \%$ of the capital costs.

The details of the cost for each of the repository canisters are presented in Tables A.3 to A.5. The reference canister cost is that of the OWPF 
IABLE A.3. Operating Cost with a Basalt Canister(a)

\begin{tabular}{|c|c|c|c|c|c|c|c|c|c|}
\hline Process & Equipment & $\begin{array}{l}\text { Fraction } \\
\text { of Cap. } \\
\text { Costs }\end{array}$ & $\begin{array}{c}\text { Operating } \\
\text { Costs, } \\
\$ \text { Thousands/yr }\end{array}$ & $\begin{array}{c}\text { Container } \\
\text { Costs, } \\
\text { Thous ands } \\
\text { Each }\end{array}$ & $\begin{array}{c}\begin{array}{c}\text { Number } \\
\text { of } \\
\text { Containers }\end{array} \\
\end{array}$ & $\begin{array}{c}\text { Total } \\
\text { Container } \\
\text { Costs, } \\
\text { \$ Thousands }\end{array}$ & $\begin{array}{c}\text { Storage, } \\
\text { Certify, } \\
\text { \$ Thousands/yr }\end{array}$ & $\begin{array}{c}\text { Total } \\
\text { Operating } \\
\text { Costs, } \\
\text { Thousands/yr }\end{array}$ & $\begin{array}{c}\text { Total } \\
\text { Operating } \\
62,000 \mathrm{MTU}, \\
5 \text { Thousands }\end{array}$ \\
\hline Shredding & Shredder & 0.08 & 154 & 5.4 & 318 & 1,703 & 159 & 2,020 & 50,000 \\
\hline $\begin{array}{l}\text { Low-Pressure } \\
\text { Compaction }\end{array}$ & $\begin{array}{l}\text { Orum } \\
\text { Compactor }\end{array}$ & 0.08 & 424 & 5.4 & 159 & 851 & 80 & 1,360 & 33,600 \\
\hline Supercompaction & Supercompactor & 0.08 & 1,250 & 5.4 & 77 & 412 & 39 & 1,700 & 42,100 \\
\hline Melting & $\begin{array}{l}\text { Induction } \\
\text { Melter }\end{array}$ & 0.08 & 1,620 & 5.4 & 56 & 300 & 28 & 1,950 & 48,200 \\
\hline
\end{tabular}

(a) Values are shown in mare significant figures than the accuracy of the data to maintain consistency in the calculations. 
IABLE A.4. Operating Costs with a Tuff Canister (a)

\begin{tabular}{|c|c|c|c|c|c|c|c|c|c|}
\hline Process & Equipment & $\begin{array}{l}\text { Fraction } \\
\text { of Cap. } \\
\text { Costs } \\
\end{array}$ & $\begin{array}{c}\text { Operating } \\
\text { Costs, } \\
\$ \text { Thousands/yr }\end{array}$ & $\begin{array}{c}\text { Container } \\
\text { Costs, } \\
\text { Thousands } \\
\text { Each } \\
\end{array}$ & $\begin{array}{c}\begin{array}{c}\text { Number } \\
\text { of } \\
\text { Containers }\end{array} \\
\end{array}$ & $\begin{array}{c}\text { Total } \\
\text { Container } \\
\text { Costs, } \\
\text { Thousands } \\
\end{array}$ & $\begin{array}{c}\text { Storage, } \\
\text { Certify, } \\
\text { \$ Thousands/yr }\end{array}$ & $\begin{array}{c}\text { Total } \\
\text { Operating } \\
\text { Costs, } \\
\$ \text { Thousands/yr } \\
\end{array}$ & $\begin{array}{c}\text { Total } \\
\text { Operating } \\
62,000 \mathrm{MTU}, \\
\text { S thousands } \\
\end{array}$ \\
\hline Shredding & Shredder & 0.08 & 154 & 5.5 & 290 & 1,584 & 145 & 1,880 & 46,700 \\
\hline $\begin{array}{l}\text { Low-Pressure } \\
\text { Compaction }\end{array}$ & $\begin{array}{l}\text { Drum } \\
\text { Compactor }\end{array}$ & 0.08 & 424 & 5.5 & 145 & 792 & 73 & 1,290 & 31,900 \\
\hline Supercompaction & Supercompactor & 0.08 & 1,250 & 5.5 & 63 & 344 & 32 & 1,620 & 40,300 \\
\hline Melting & $\begin{array}{l}\text { Induction } \\
\text { Melter }\end{array}$ & 0.08 & 1,620 & 5.5 & 36 & 197 & 18 & 1,830 & 45,400 \\
\hline
\end{tabular}

(a) Values are shown in more significant figures than the accuracy of the data to maintain consistency in the calculations. 
IABLE A.5. Operating Costs with a Salt Canister(a)

\begin{tabular}{|c|c|c|c|c|c|c|c|c|c|}
\hline Process & Equipment & $\begin{array}{l}\text { Fraction } \\
\text { of Cap. } \\
\text { Cost } 5 \\
\end{array}$ & $\begin{array}{c}\text { Operating } \\
\text { Costs, } \\
\text { Thousands/yr }\end{array}$ & 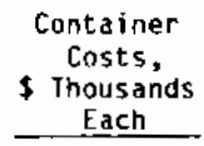 & $\begin{array}{c}\text { Number } \\
\text { of } \\
\text { Containers } \\
\end{array}$ & $\begin{array}{c}\text { Total } \\
\text { Container } \\
\text { Costs, } \\
\$ \text { Thoussands } \\
\end{array}$ & $\begin{array}{c}\text { Storage, } \\
\text { Certify, } \\
\text { Ihousands/yr } \\
\end{array}$ & $\begin{array}{c}\text { Total } \\
\text { Operating } \\
\text { Costs, } \\
\text { \$Thousands } / y \text {. }\end{array}$ & $\begin{array}{c}\text { Total } \\
\text { Operating } \\
62,000 \text { MTU, } \\
\$ \text { Thousands }\end{array}$ \\
\hline Shredding & Shredder & 0.08 & 154 & 5.3 & 329 & 1,750 & 165 & 2,070 & 51,300 \\
\hline $\begin{array}{l}\text { Low-Pressure } \\
\text { Compaction }\end{array}$ & $\begin{array}{l}\text { Drum } \\
\text { Compactor }\end{array}$ & 0.08 & 424 & 5.3 & 164 & 872 & 82 & 1,380 & 34,200 \\
\hline Supercompaction & Supercompactor & 0.08 & 1,250 & 5.3 & 80 & 425 & 40 & 1,710 & 42,500 \\
\hline Melting & $\begin{array}{l}\text { Induction } \\
\text { Melter }\end{array}$ & 0.08 & 1,620 & 5.3 & 46 & 245 & 23 & 1,890 & 46,800 \\
\hline
\end{tabular}

(a) Values are shown in more significant figures than the accuracy of the data to maintain consistency in the calculations. 
canister, which is currently expected to cost about $\$ 4400$. This cost was scaled to the size of the canisters used in this study. The cost of canisters is the most significant for the high-volume waste forms. The cost of assay and certification is a direct function of the number of containers.

\section{A.3 TOTAL TREATMENT COSTS}

The sums of the capital and operating costs of treatment of the 62,000 MTU of spent fuel wastes are shown for basalt, tuff, and salt disposal in Tables A.6 to A.8, respectively. The decommissioning costs, which have been calculated based on $12 \%$ of capital costs are also shown. 
TABLE A.6. Total Treatment Costs with a Basalt Canister (Costs in $\$$ Thousands)(a)

\begin{tabular}{|c|c|c|c|c|c|}
\hline Process & $\begin{array}{c}\text { Equipment and } \\
\text { Facility } \\
\text { Capital Costs }\end{array}$ & $\begin{array}{l}\text { Interim Storage } \\
\text { Capital Costs }\end{array}$ & $\begin{array}{c}\text { Total } \\
\text { Operating Costs } \\
\end{array}$ & $\begin{array}{c}\text { Decomrnissioning } \\
\text { Costs }\end{array}$ & $\begin{array}{c}\text { Total } \\
\text { Treatment Costs } \\
\end{array}$ \\
\hline Shredding & 1,920 & 10,300 & 50,000 & 1,470 & 63,700 \\
\hline $\begin{array}{l}\text { Low-Pressure } \\
\text { Compaction }\end{array}$ & 5,300 & 5,910 & 33,600 & 1,350 & 46,100 \\
\hline Supercompaction & 15,600 & 3,310 & 42,100 & 2,270 & 63,300 \\
\hline Melting & 20,200 & 2,120 & 48,200 & 2,680 & 73,300 \\
\hline
\end{tabular}

(a) Values are shown in more significant figures than the accuracy of the data to maintain consistency in the calculations. 
TA8LE A.7. Total Treatment Costs with a Tuff Canister (Costs in \$ Thousands)(a)

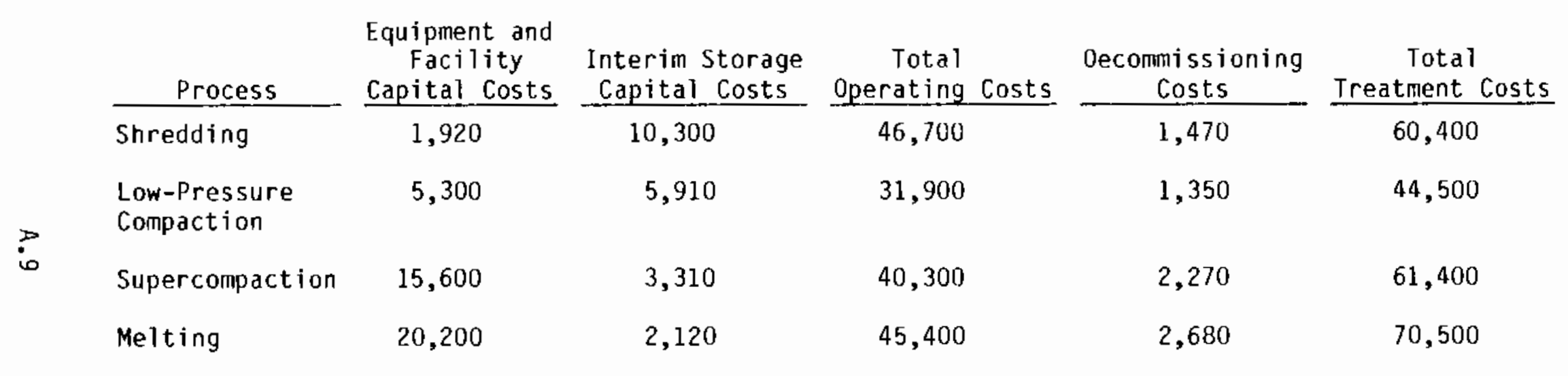

(a) Values are shown in more significant figures than the accuracy of the data to maintain consistency in the calculations. 
IABLE A.8. Total Treatment Costs with a Salt Canister (Costs in $\$$ Thousands)(a)

\begin{tabular}{|c|c|c|c|c|c|}
\hline Process & $\begin{array}{l}\text { Equipment and } \\
\text { Facility } \\
\text { Capital Costs } \\
\end{array}$ & $\begin{array}{l}\text { Interim Storage } \\
\text { Capital Costs }\end{array}$ & $\begin{array}{c}\text { Total } \\
\text { Operating Costs }\end{array}$ & $\begin{array}{l}\text { Decommissioning } \\
\text { Costs } \\
\end{array}$ & $\begin{array}{c}\text { Total } \\
\text { Treatment Costs }\end{array}$ \\
\hline Shredding & 1,920 & 10,300 & 51,300 & 1,470 & 65,000 \\
\hline $\begin{array}{l}\text { Low-Pressure } \\
\text { Compaction }\end{array}$ & 5,300 & 5,910 & 34,200 & 1,350 & 46,700 \\
\hline Supercompaction & 15,600 & 3,310 & 42,500 & 2,270 & 63,600 \\
\hline Melting & 20,200 & 2,120 & 46,800 & 2,680 & 71,800 \\
\hline
\end{tabular}

(a) Values are shown in more significant figures than the accuracy of the data to maintain consistency in the calculations. 


\section{APPENDIX B}

TRANSPORTATION COSTS FOR NFBH TREATMENT ALTERNATIVES 
APPENDIX B

\section{TRANSPORTATION COSTS FOR NFBH TREATMENT ALTERNATIVES}

Detailed transportation costs for each of the canister sizes are presented in Tables B.1 through B.3. Each table applies to one type of repository canister. The number of canisters, number of shipments, number of cask-days, number of casks, maintenance costs, and shipping costs are shown on an annual basis. The tables also include 1 ifetime costs based on 25 years of operation. The casks are assumed to have a lifetime of less than 25 years and to need one replacement during the 25 years. Thermal, weight, and size limits for the casks are discussed in the body of the report. 
TABLE B.1. Transportation Costs for NFBH Treatment Alternatives with Basalt Disposal(a)

\begin{tabular}{|c|c|c|c|c|c|c|c|c|c|c|c|c|}
\hline Process & $\begin{array}{l}\text { Canisters } \\
\text { Per Year } \\
\end{array}$ & $\begin{array}{l}\text { Canisters } \\
\text { Per Cask }\end{array}$ & $\begin{array}{l}\text { Shipments } \\
\text { Per Year. }\end{array}$ & $\begin{array}{l}\text { Cask-Days } \\
\text { Per Year } \\
\end{array}$ & $\begin{array}{l}\text { Number of } \\
\text { Casks }\end{array}$ & $\begin{array}{c}\text { Cast } \\
\text { Cost, } \\
\$ \text { Thousands } \\
\end{array}$ & $\begin{array}{l}\text { Maint enance, } \\
\text { S Thous ands } / Y\end{array}$ & $\begin{aligned} & \text { Shipping, } \\
& 5 \text { Thousands } / Y \\
&\end{aligned}$ & $\frac{11}{\text { Capital }}$ & $\begin{array}{l}\text { Setime Costs, } \\
\text { Maintenance }\end{array}$ & $\begin{array}{l}\text { 5housan } \\
\text { Shfpping }\end{array}$ & ds \\
\hline Shredding & 318 & 2 & 159 & 3,700 & 12 & 30,000 & 1,500 & 7,030 & 60,000 & 37,500 & 175,000 & 273,090 \\
\hline $\begin{array}{l}\text { Low-pressure } \\
\text { compaction }\end{array}$ & 159 & 2 & 80 & 1,820 & 6 & 15,000 & 750 & 3,500 & 30,000 & 18,800 & 88,400 & 137,000 \\
\hline Supercampaction & $n 7$ & 2 & 39 & 881 & 3 & 7,500 & 375 & 1,720 & 15,000 & 9,380 & 43,100 & 67,500 \\
\hline Melting & 56 & 2 & 28 & 641 & 2 & 5,000 & 250 & 1,240 & 10,000 & 6,250 & 31,000 & 47,200 \\
\hline
\end{tabular}

iv (a) Values rounded to three significant figures, which exceeds the accuracy of the data. 
TABLE B.2. Transportation Costs for NFBH Treatment Alternatives with Tuff Disposal(a)

\begin{tabular}{|c|c|c|c|c|c|c|c|c|c|c|c|c|}
\hline Process & $\begin{array}{l}\text { Canisters } \\
\text { Per Year }\end{array}$ & $\begin{array}{l}\text { Canisters } \\
\text { Per Cask }\end{array}$ & $\begin{array}{l}\text { Shipments } \\
\text { Per Year }\end{array}$ & $\begin{array}{l}\text { Cask-Days } \\
\text { Per Year }\end{array}$ & $\begin{array}{l}\text { Number af } \\
\text { Casks }\end{array}$ & $\begin{array}{c}\text { Cast } \\
\text { Cost } \\
\$ \text { Thousands }\end{array}$ & $\begin{array}{l}\text { Maintenance, } \\
\text { I Thousands } / Y\end{array}$ & $\begin{aligned} \text { Shipping, } \\
\text { Shousands/Y } \\
\end{aligned}$ & $\frac{\text { Laj }}{\text { Capitai }}$ & $\begin{array}{l}\text { fetime Costs, } \\
\text { Maintenance }\end{array}$ & $\begin{array}{l}\text { Thousan } \\
\text { Shipging }\end{array}$ & ds \\
\hline Shredding & 290 & 2 & 145 & 3,320 & 11 & 27,500 & 1,380 & 6,410 & 55,000 & 34,400 & 150,000 & 250,000 \\
\hline $\begin{array}{l}\text { Low-pressure } \\
\text { compaction }\end{array}$ & 145 & 2 & 73 & 1,660 & 6 & 15,000 & 750 & 3,280 & 30,000 & 18,800 & 80,700 & 129,000 \\
\hline Supercompact ion & 63 & 2 & 32 & 721 & 2 & 5,000 & 250 & 1,410 & 10,000 & 6,250 & 35,400 & 51,600 \\
\hline Meltíng & 36 & 1 & 36 & 824 & 3 & 7,500 & 375 & 1,590 & 15,000 & 9,380 & 39,800 & 64,200 \\
\hline
\end{tabular}

(a) Values rounded to three significant figures, which exceeds the accuracy of the data. 
TABLE B.3. Transportation Costs for NFBH Treatment Alternatives with Salt Disposal(a)

\begin{tabular}{|c|c|c|c|c|c|c|c|c|c|c|c|c|}
\hline & Canisters & Canisters & Shipments & Cask-Days & Number of & $\begin{array}{l}\text { Cast } \\
\text { Cost }\end{array}$ & Maintenance, & Shipping, & & fet jme costs, & S Thousan & \\
\hline Process & Per Year & Per Cask & Per Year & Per Year & Casks & $\$$ Thousands & S Thousands /Y & $\$$ Thousands/Y & iapital & Maintenance & Shipping & Tota! \\
\hline Shredding & 329 & 2 & 165 & 3,770 & 13 & 32,500 & 1,630 & 7,300 & 65,000 & 40,600 & 182,000 & 288,000 \\
\hline $\begin{array}{l}\text { Low pressure } \\
\text { compaction }\end{array}$ & 164 & 2 & 82 & 1,880 & 6 & 15,000 & 750 & 3,620 & 30,000 & 18,800 & 90,600 & 139,000 \\
\hline Supercompaction & 80 & 2 & 40 & 916 & 3 & 7,500 & 375 & 1,770 & 15,000 & 9,380 & 44,200 & 68,600 \\
\hline Melting & 46 & 2 & 23 & 526 & 2 & 5,000 & 250 & 1,020 & 10,000 & 6,250 & 25,400 & 41,700 \\
\hline
\end{tabular}

(a) values rounded to three significant figures, which exceeds the accuracy of the data. 


\section{DISTRIBUTION}

No. of

Copies

OFFSITE

30 DOE Technical Information Center

7 Geologic Repository Division DOE Office of Civilian

Radioactive Waste Management Forresta? Building Washington, DC 20585

ATTN: L. H. Barrett, RW-33

C. A. Conner

R. J. Hilley, RW-30

D. E. Shelor

R. Stein, RW-23

C. R. Cooley, RW-4

S. H. Kale

3 DOE Office of Defense Waste \& Transportation Management GTN

Washington, DC 20545

ATTN: G. H. Daley, DP-124

J. E. Lytle, DP-12

T. C. Chee, DP-123

5 DOE Office of Remedial Action

\& Waste Technology GTN

Washington, DC 20545

ATTN: J. A. Coleman, NE-24

T. W. McIntosh, NE-24

W. R. Voigt, NE-20

H. F. Waiter, NE-24

H. E. Stilling, NE-24

A. T. Clark

Division of Fuel Material

Safety

Nuclear Regulatory Commission

Washington, OC 20555
No. of

Copies

V. Stel10

Office of the Executive

Director for Operations

Mail Station 6209

Nuclear Regulatory Commission

Washington, DC 20555

G. L. Sjoblom

Environmental Protection Agency

Office of Radiation Programs

401 M Street, S.W.

Washington, DC 20460

3 DOE Albuquerque Operations Office

P.0. Box 5400

Albuquerque, NM 87185

ATTN: K. A. Carlson

M. H. McFadden

J. McGough

P. G. Hagan

Joint Integration Office

Bldg. 3, 2nd Floor

2201 San Pedro N.E.

Albuquerque, NM 87110

2 DOE Idaho Operations Office

550 Second Street

Idaho Falls, ID 83401

ATTN: J. D. Hamric

S. T. Hinschberger

F. T. Fong

DOE San Francisco Operations

1333 Broadway

0akland, CA 94612

M. R. Jugan

OOE Oak Ridge Operations Office

P.0. Box E

Oak Ridge, TN 37830 
No. of

Copies

J. 0. Neff

DOE National Waste Program Office

505 King Avenue

Columbua, OH 43201

W. J. Brumley

DOE Savannah River Operations Office

P.0. Box A

Aiken, SC 29801

D. L. Vieth

DOE Nevada Operations Office

P.0. Box 14100

Las Vegas, NV 89114

2 Argonne National Laboratory

9700 South Cass Avenue

Argonne, IL 60439

ATTN: M. J. Steindler

L. E. Trevorrow

C. S. Abrams

Argonne National Laboratory

P.0. Box 2528

Idaho Falls, ID 8340 ?

3 Battelle Memorial Institute

Project Management Division

$505 \mathrm{King}$ Avenue

Columbus, OH 43201

ATTN: W. A. Carbeiner

W. S. Madia

B. Rawles

L. D. Ramspott

Lawrence Livermore Nationa? Laboratory

University of California

P.0. Box 808

Livermore, CA 94550
No. of

Copies

D. T. Oakley, MS 671

Los Alamos Scientific Laboratory

P.0. Box 1663

Los Alamos, NM 87544

5 Oak Ridge National Laboratory

P.0. Box $Y$

Oak Ridge, TN 37830

ATTN: J. 0. Blomeke

W. D. Burch

R. T. Jubin

K. J. Notz

T. H. Row

3 Sandia Laboratories

P.0. Box 5800

Albuquerque, NM 87185

ATTN: R. W. Lynch

W. Weart

Technical Library

J. R. Berreth

Westinghouse Idaho Nuclear

Co., Inc.

P.0. Box 4000

Idaho Falls, ID 83401

E. J. Hennelly

E. I. du Pont de Nemours Company

Savannah River Laboratory

Aiken, SC 29801

E. A. Jennrich

EG\&G Idaho

P.0. Box 1625

Idaho Falls, ID 83415

J. L. Jardine

Bechtel National, Inc.

P.0. Box 3965

San Francisco, CA 94119 
No. of

Copies

ONSITE

12 DOE Richland Operations Office

J. H. Anttonen

E. A. Bracken

G. J. Bracken

C. R. Delannoy

R. B. Goranson

R. D. Izatt

N. T. Karagianes

M. J. Plahuta

J. L. Rhoades

M. W. Shupe

J. D. White

J.K.W. Wukelik

8 Rockwell Hanford Operations

H. E. McGuire

J. W. Patterson

R. D. Prosser

R. D. Thompson

T. B. Venziano

D. D. Wodrich

R. D. Wojt a sek

File Copy

UNC United Nuclear Industries

T. E. Dabrowski/J. Kyriazis

2 Westinghouse Hanford Company

R. E. Lerch

J. D. Watrous
No. of

Copies

7) Pacific Northwest Laboratory

C. R. Allen

W. W. Ballard

G. H. Beeman

A. J. Boegel

W. F. Bonner

J. L. Braitman

R. A. Brouns

G. H. Bryan

H. C. Burkholder

J. R. Carrell

L. L. Clark (3)

T. T. Claudson

B. M. Cole

R. E. Heineman

D. K. Hilliard

L. K. Holton

D. E. Knowiton

M. R. Kreiter

L. T. Lakey

D. McCarthy

P. N. McDuffie

J. L. McE Iroy

R. W. Mckee

G. W. McNair

D. F. Newman

K. H. Oma (5)

A. M. Platt

W. A. Ross (20)

K. J. Schneider

R. I. Smith

M. B. Triplett

R. S. Wegneg

M. K. White (5)

T. W. Wood (Washington)

Publishing Coordination (2)

Technical Information (5) 
